\title{
Compounds from African Medicinal Plants with Activities Against Selected Parasitic Diseases: Schistosomiasis, Trypanosomiasis and Leishmaniasis
}

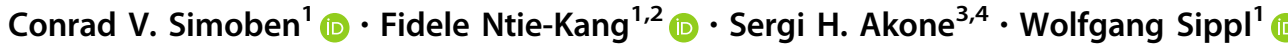

Received: 22 February 2018 / Accepted: 26 April 2018/Published online: 9 May 2018

(c) The Author(s) 2018

\section{Abstract}

Parasitic diseases continue to represent a threat on a global scale, particularly among the poorest countries in the world. This is particularly because of the absence of vaccines, and in some cases, resistance against available drugs, currently being used for their treatment. In this review emphasis is laid on natural products and scaffolds from African medicinal plants (AMPs) for lead drug discovery and possible further development of drugs for the treatment of parasitic diseases. In the discussion, emphasis has been laid on alkaloids, terpenoids, quinones, flavonoids and narrower compound classes of compounds with micromolar range activities against Schistosoma, Trypanosoma and Leishmania species. In each subparagraph, emphasis is laid on the compound subclasses with most promising in vitro and/or in vivo activities of plant extracts and isolated compounds. Suggestions for future drug development from African medicinal plants have also been provided. This review covering 167 references, including 82 compounds, provides information published within two decades (1997-2017).

\section{Graphical Abstract}

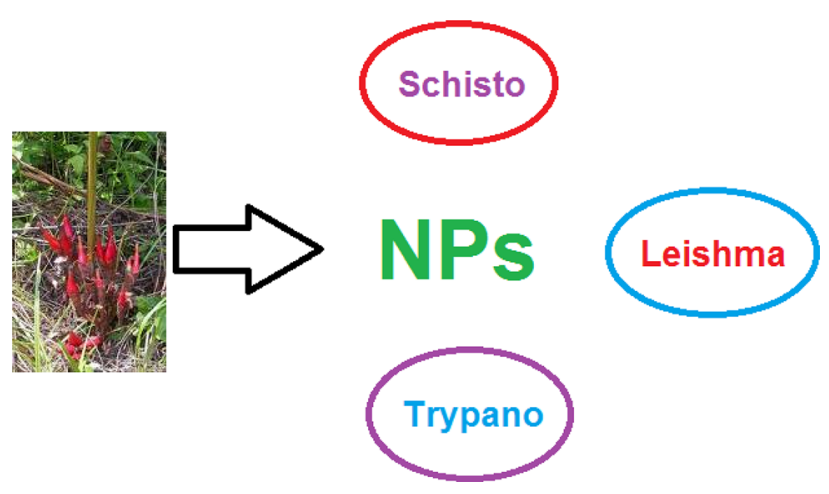

Keywords African medicinal plants · Leishmaniasis · Natural products · Parasitic diseases · Schistosomiasis · Trypanosomiasis

Fidele Ntie-Kang

ntiekfidele@gmail.com

1 Institute of Pharmacy, Martin-Luther University of HalleWittenberg, Wolfgang-Langenbeck-Str. 4, 06120 Halle (Saale), Germany

2 Department of Chemistry, Faculty of Science, University of Buea, P.O. Box 63, Buea 00237, Cameroon
3 Institute of Pharmaceutical Biology and Biotechnology, Heinrich-Heine-University, Universitaetsstrasse1, Geb. 26.23, Duesseldorf 40225, Germany

4 Department of Chemistry, Faculty of Science, University of Douala, PO Box 24157, Douala 00237, Cameroon 


\section{Introduction}

Parasites are considered as organisms that obtain their food by eating other organisms or their products in nature. These diseases continue to be a cause of considerable morbidity and mortality globally [1-4], including Trypanosomiasis (African sleeping sickness and Chagas disease) [5-7], Leishmaniasis [8] and Schistosomiasis [9, 10]. They threaten almost one-third of the world's population, the most numerous incidents being recorded in over 100 tropical and developing countries and territories, Fig. 1 [11-13]. The African region recorded the most death-related cases, especially amongst infants below the age of 5 and pregnant women. Schistosomiasis, caused by parasites of the Schistosoma genus are responsible for about 200 million sickness cases and about 280,000 death-related incidents annually worldwide [9, 10, 14]. Only one drug (praziquantel) has been proven to be effective in the treatment of human Schistosomiasis, with no vaccine available or in development so far [15-21]. Serious concerns about drug selectivity and resistance were raised in 2013 when over 30 million people were treated in SubSaharan Africa [20]. Moreover, observed resistance and reduced efficiency of praziquantel in laboratory strains have prompted the search for alternative therapeutic strategies [20-27].

Trypanosomiasis, which represents several diseases caused by parasites of the genus Trypanosoma, is also of interest [5, 27-29]. This disease, which is much arguably the most important disease of man and domesticated animals, accounts for over 8 million reported annual cases globally, especially in the tropical regions of Latin America and Africa [30, 31]. Besides, great socioeconomic effects on the endemic areas by this disease are forecast if inadequate attention (both at the communal, national, and international levels) is not given [7, 29, 32-34]. Leishmaniasis is caused by parasites of the Leishmania type, which is also transmitted by certain types of sandflies [35, 36]. The diseases are reported by the WHO to be responsible for about 1 million new cases leading to approximately 30,000 deaths annually on a global scale. The major cause is

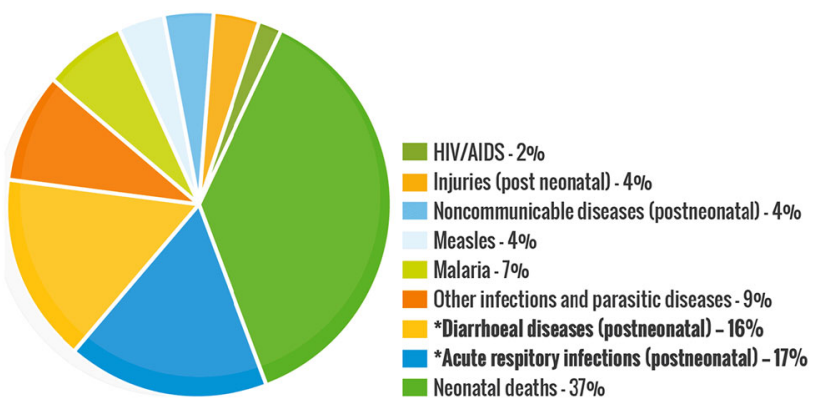

Fig. 1 Global statistics for disease burdens in 2017 linked to environmental changes and affects mainly the very poor populations $[37,38]$. These three diseases represent a real burden to the lives of millions of persons and their domesticated animals. The trio is capable of inflicting long-term disability and social stigmatisation, which can ultimately lead to a highly unproductive population and eventually result in economic loss and the slowdown of a country's development.

With the absence of any vaccine targeting any parasites and resistance against the already existing anti-parasitic drugs, research efforts have been employed and encouraged towards the search for new, cheaper, potent and effective drugs to treat these diseases. Medicinal plants represent a potential source of new drugs. This is because natural products (NPs) from organisms such as animals, fungi and the higher plants have been known to be good sources of pharmacologically active compounds against several ailments, including parasitic infections. Moreover, NPs are believed to have significant advantages as lead molecules over synthetic molecules [39-49]. The criteria for choosing a particular natural product for studies are either based on the pre-existing knowledge on the traditional use of the source species in therapy (ethnobotanical knowledge) or the search for structurally related molecules with known pharmacologically active agents from chemical databases [49-54]. The African continent is highly diverse ethnobotanically. This might explain why about $80 \%$ of the population tends to rely on medicinal plants as a primary source of healthcare [55-67]. It is our goal to provide evidence of the efficacy and potency of plants used in traditional medicine against parasitic infections. The systematic documentation of the plant-based chemical constituents of African traditional medicine and attempting to using in silico procedures to investigate their modes of action are ongoing efforts [44-46, 52, 53], particularly on the isolated compounds from African medicinal plants (AMPs) with evaluated in vitro and/or in vivo activities against Trypanosomiasis [68-74], Schistosomiasis, Leishmaniasis [72-74] and other parasitic diseases [4]. However, the most recent review dates about 3 years back and was focused only on plants collected from Nigeria. Thus, an updated review that covers the entire continent for these three parasitic diseases is required now. The information presented herein was retrieved by searching literature from major international journals on natural products and medicinal chemistry, alongside available M.Sc. and Ph.D. theses and online databases [54, 75]. The information gathered is discussed under the main compound classes, as presented below and summarised in Tables 1, 2, and 3 . 


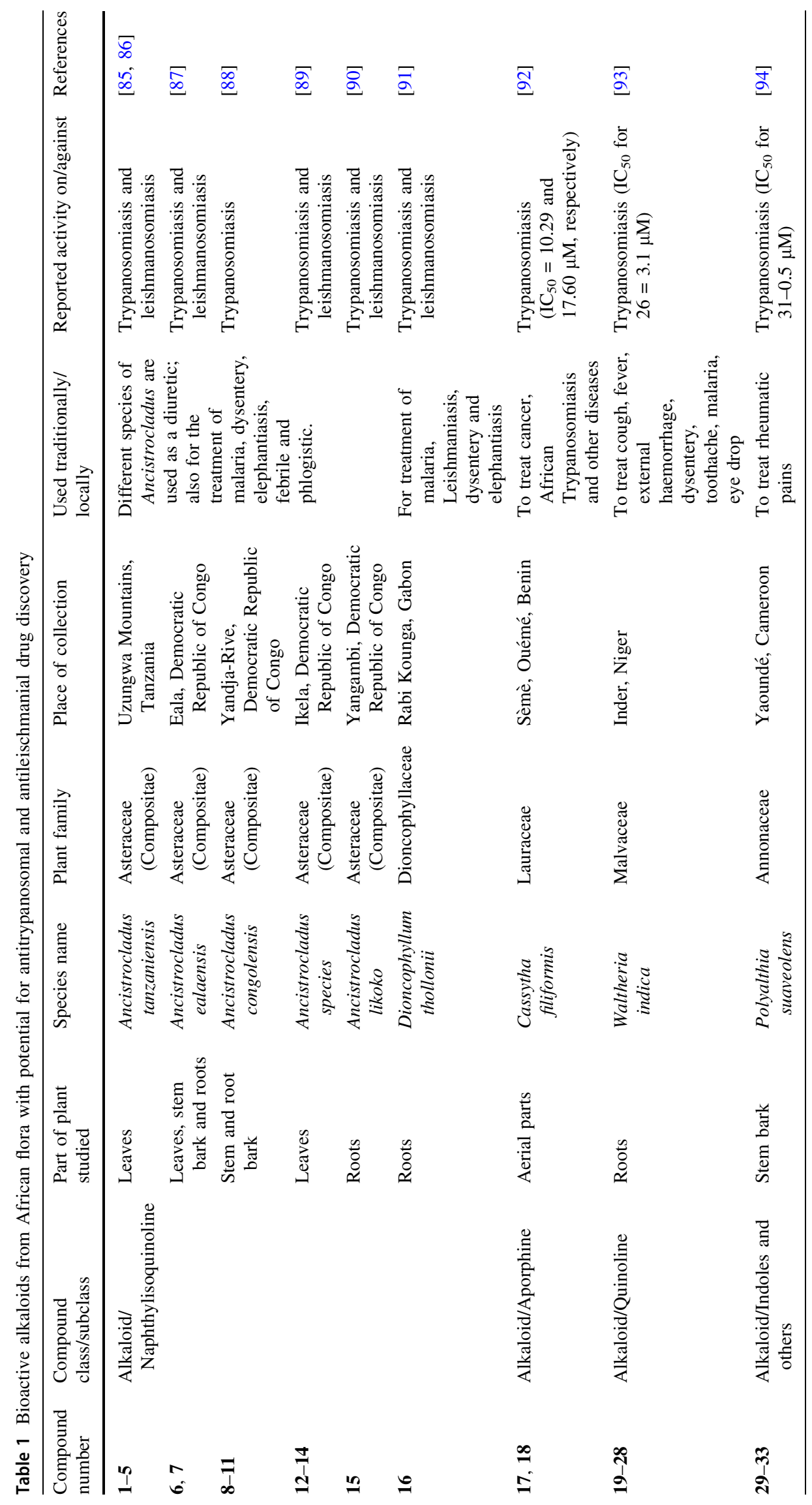




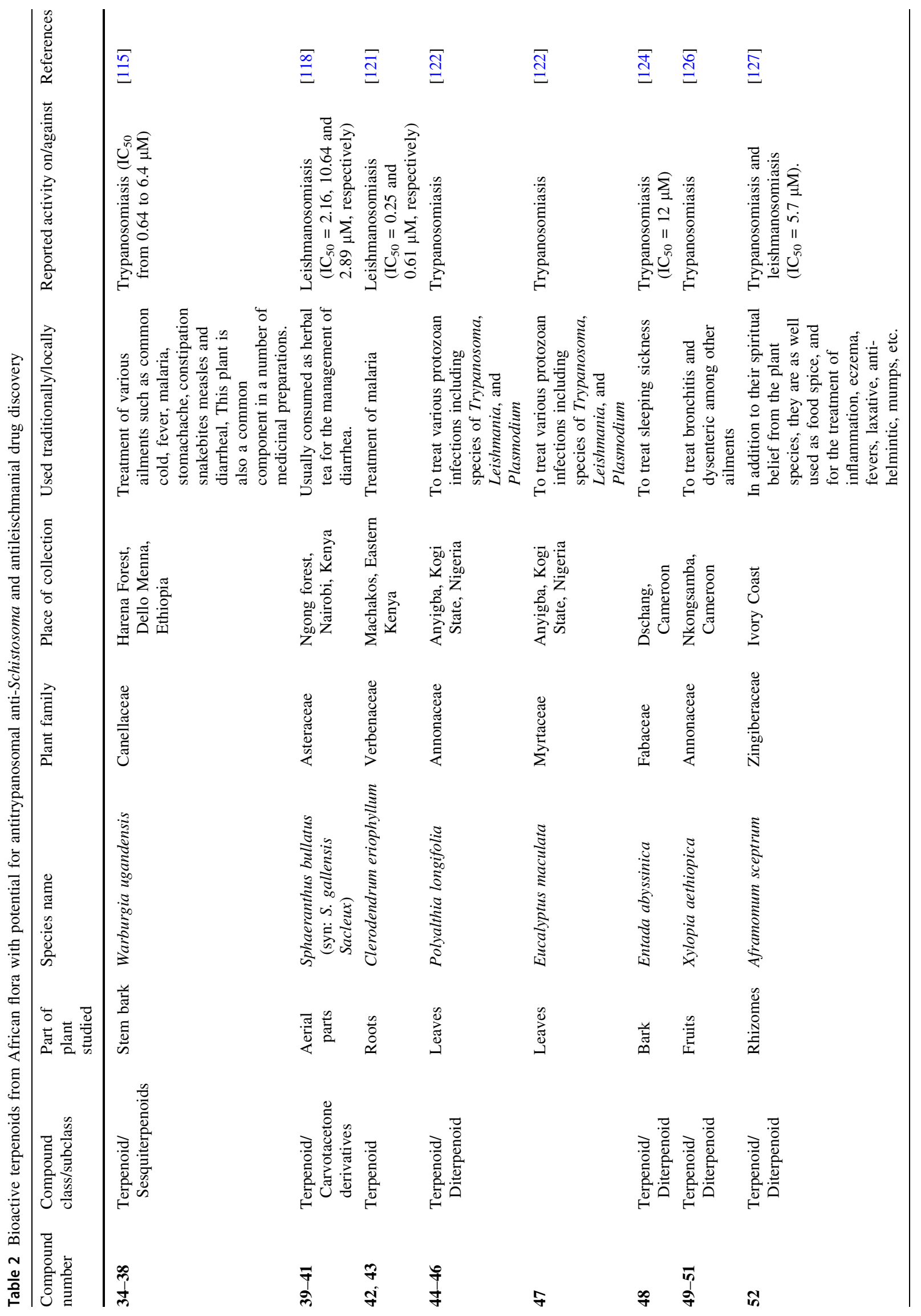




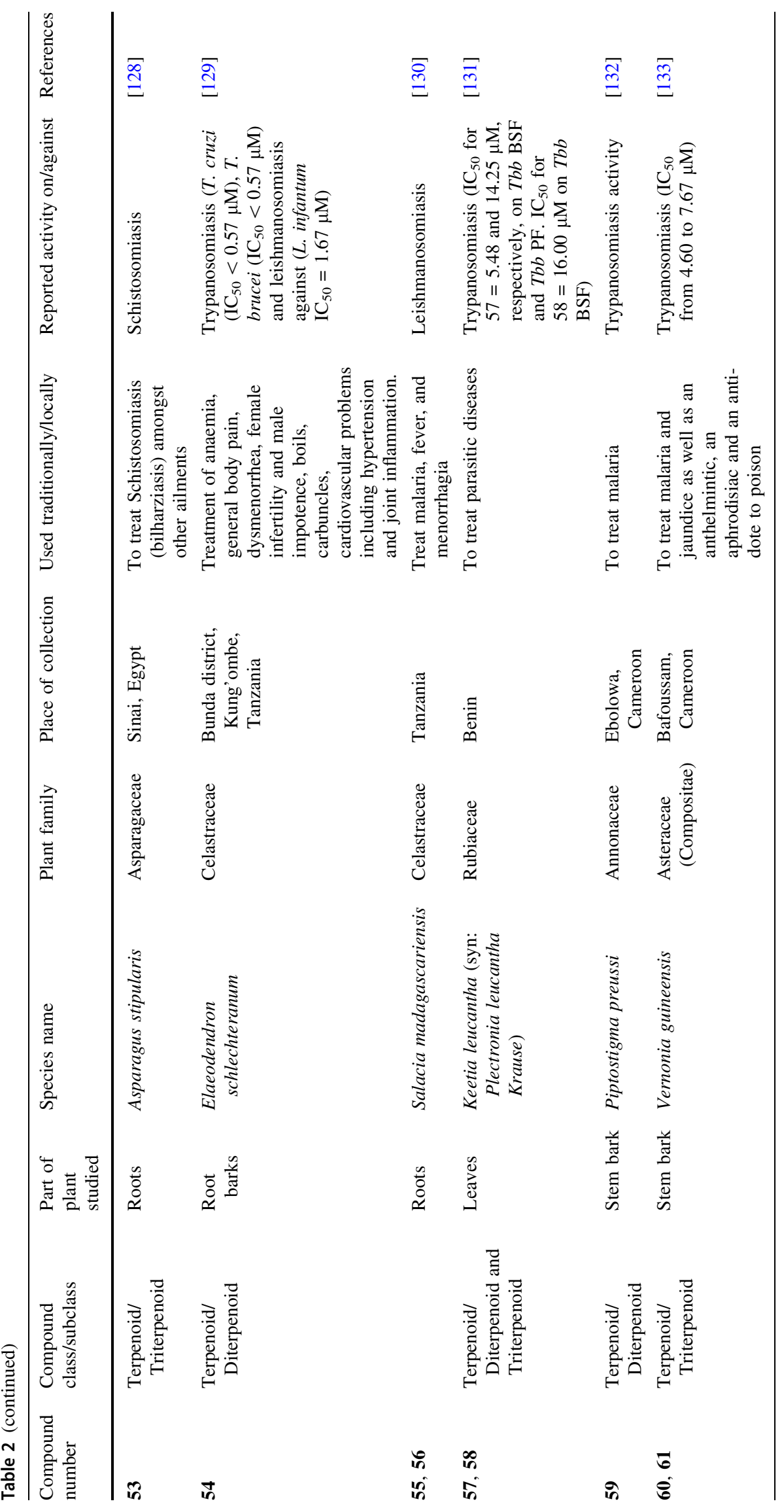




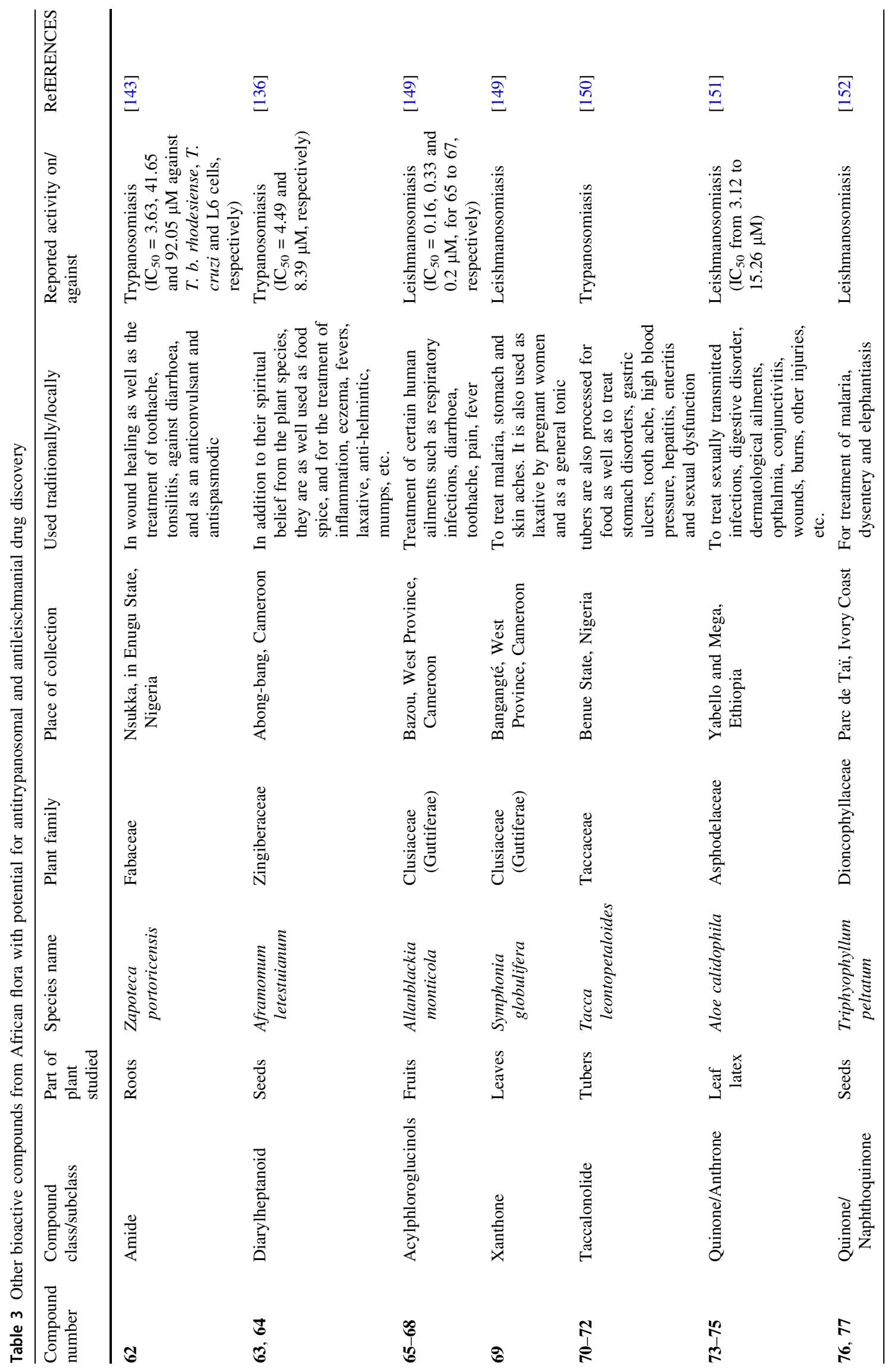




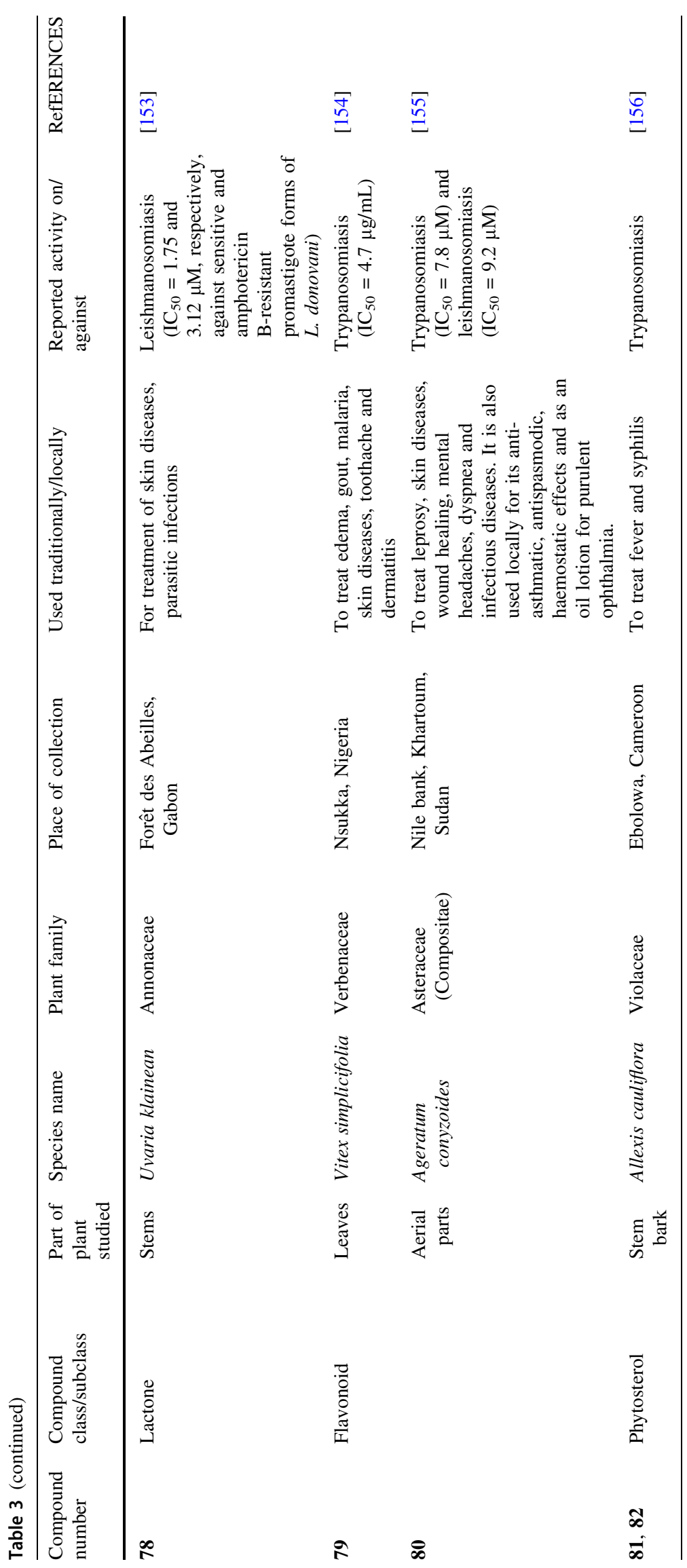




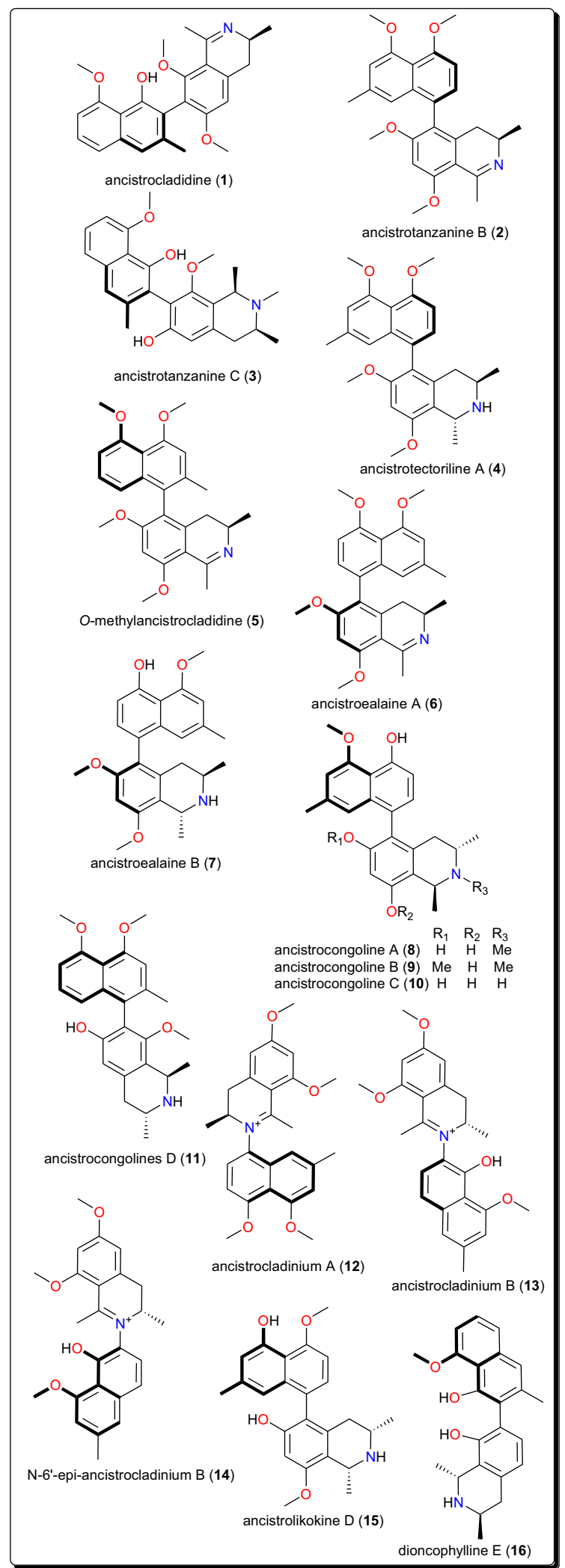

Fig. 2 Antiprotozoal naphthylisoquinoline alkaloids

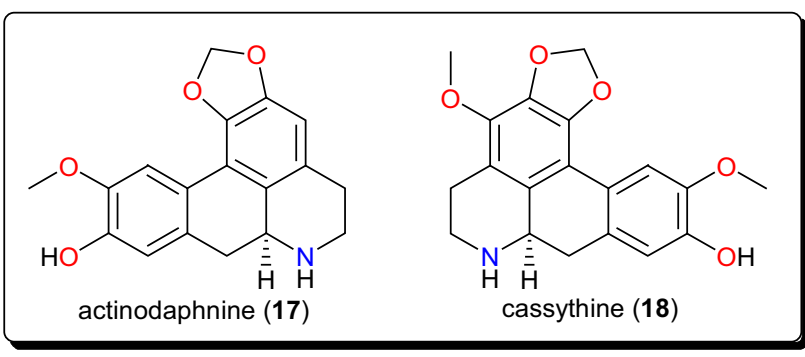

Fig. 3 Aporphine alkaloids with trypanosidal potencies

\section{Alkaloids}

This class is characterized by nitrogen-containing compounds that are naturally occurring. Diverse species (fungi, plants, animals) have yielded several bioactive alkaloids against a broad range of diseases [76-84]. Table 1 summarises the alkaloids (compounds 1-33) isolated from AMPs and evaluated against these parasitic diseases, while Figs. 2, 3, 4 and 5 show a selection of some promising alkaloidal compounds, based on their evaluated activity $(<12.41 \mu \mathrm{M})$.

\subsection{Naphthylisoquinolines}

The leaves, stem bark and roots of Ancistrocladus sp. (Ancistrocladaceae) are known to be rich sources of naphthylisoquinoline alkaloids (Fig. 2) [85-91]. Ancistrocladidine (1), ancistrotanzanines B (2), and C (3), ancistrotectoriline A (4), $O$-methylancistrocladidine (5), ancistroealaines A (6) and B (7), ancistrocongolines A-D (8-11), ancistrocladiniums $\mathrm{A}$ (12) and B (13), N-6'-epiancistrocladinium B (14), ancistrolikokine D (15) and dioncophylline E (16) are few examples of naphthylisoquinoline antiparasitic alkaloids from Ancistrocladus sp. and Dioncophyllum thollonii (Dioncophyllaceae).

The evaluation of the biological activities of these compounds showed them to be a rare set and promising class of antiprotozoal and antiviral agents, which are only found in plants of the Ancistrocladaceae and Dioncophyllaceae, mostly found in Africa. Their anti-Trypanosoma activities are evident (e.g., with $\mathrm{IC}_{50}$ values ranging from 0.17 to $12.41 \mu \mathrm{M}$ against Trypanosoma brucei rhodesiense), alongside good to moderate activities against Trypanosoma cruzi and Leishmania donovani. It might be worth mentioning that the isoquinoline scaffold has also been explored synthetically for the discovery of novel antiprotozoals and antimicrobials [85, 86, 95-97].

\subsection{Aporphines}

Other bioactive alkaloids include the aporphines (Fig. 3); actinodaphnine (17) and cassythine (18) from Cassytha 


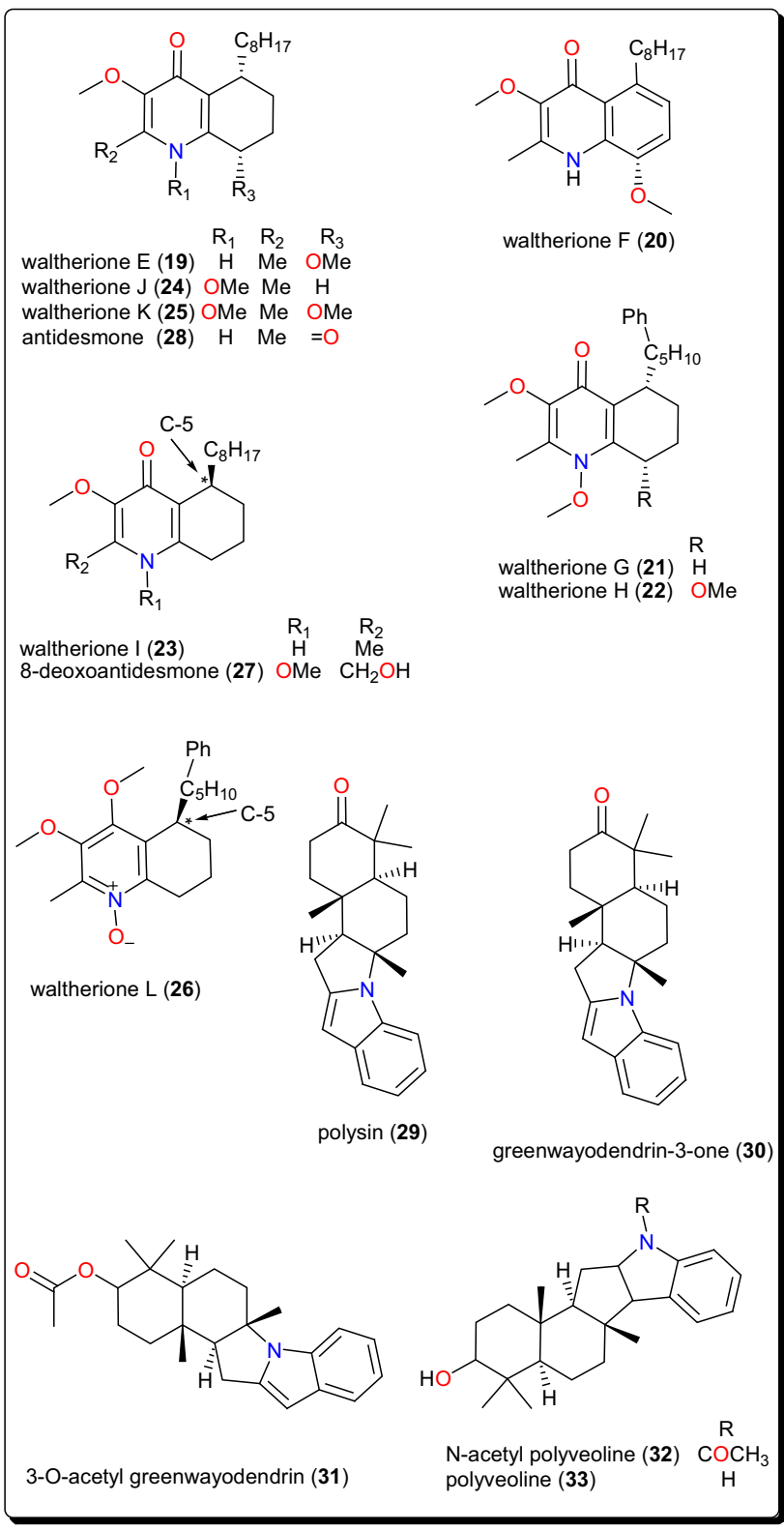

Fig. 4 Quinoline, indoles and other alkaloids showing activities against Trypanosoma species

filiformis (Lauraceae), a plant whose alkaloidal extract showed activity against $T$. b. brucei (with an $\mathrm{IC}_{50}$ value of $2.2 \mu \mathrm{g} / \mathrm{mL}$ ). This confirmed the use of this plant in African folkloric medicine to treat African Trypanosomiasis and other diseases [92, 98, 99]. The isolated compounds displayed antitrypanosomal activities, with $\mathrm{IC}_{50}$ values of 10.29 and $17.60 \mu \mathrm{M}$ for compounds $\mathbf{1 7}$ and $\mathbf{1 8}$, respectively. Although, the compounds showed low selectivity indices to $\mathrm{HeLa}$ cells (e.g., for actinodaphnine, $\mathrm{IC}_{50}$ $(\mathrm{HeLa}) / \mathrm{IC}_{50}(T$. b. brucei $\left.)<5\right)$, when compared with the alkaloidal fraction (selectivity index $=16$ ), they represent good starting scaffolds that could be optimised in order to improve the efficacy and selectivity in the search for new bioactive molecules with trypanocidal effects.

\subsection{Quinolines}

Other trypanocidal alkaloids include the quinolines (Fig. 4); waltheriones E-L (19-26), 8-deoxoantidesmone (27) and antidesmone (28) from Waltheria indica (Malvaceae) [93]. This plant is used in traditional medicine for the treatment of several ailments, including malaria [63, 100-104]. The dichloromethane root extract showed activities against $T$. cruzi $\left(\mathrm{IC}_{50}=0.74 \mu \mathrm{g} / \mathrm{mL}\right), T$. $b$. brucei (2.3\% survival at $20 \mu \mathrm{g} / \mathrm{mL}$ ) and T. b. rhodesiense $\left(\mathrm{IC}_{50-}\right.$ $=17.4 \mu \mathrm{g} / \mathrm{mL}$ ) [93]. With the exception of waltherione $\mathrm{L}$ (26), with a slightly higher $\operatorname{IC}_{50}(3.1 \mu \mathrm{M})$, the isolated compounds all displayed potent growth inhibition toward the amastigote form of T. cruzi (the Tulahuen C4 strain), with $\mathrm{IC}_{50}$ values lower than that of the reference drug benznidazole $\left(\mathrm{IC}_{50}=2.9 \mu \mathrm{M}\right)$. Structure-activity relationships (SARs) provide suggestions that, a methoxy group, bound to the nitrogen atom is important for activity (e.g., as in compounds 22, 24 and 25). This group at this position increased the lethality of $T$. cruzi. Furthermore, the absolute configuration $(5 R)$ (as in compounds $\mathbf{2 3}, \mathbf{2 6}, \mathbf{2 7}$ ) seems to result in a decrease of activity, while the presence of an $\mathrm{N}$-oxide function (as in compound 26) is detrimental for $T$. cruzi inhibitory activity (Fig. 5). Finally, a comparison of the $\mathrm{IC}_{50}$ values of the isolated compounds against $T$. brucei sp. and $T$. cruzi highlighted selective toxicity towards the latter. This suggests that these molecules (or the waltherione scaffold) is a potential starting point for new safe antitrypanocidal drug development, although antidesmone (28) has already been patented for its potential as an antiprotozoal drug since 2003 [93, 105, 106].

\subsection{Indoles and Other Alkaloids}

Polysin (29), an indolosesquiterpene alkaloid from Polyalthia suaveolens (Annonaceae), was isolated together with the known alkaloids (Fig. 4); greenwayodendrin-3-one (30), 3-O-acetyl greenwayodendrin (31), $\mathrm{N}$-acetyl polyveoline (32) and polyveoline (33). These alkaloids have demonstrated interesting activities on selected glycolytic enzymes, e.g., phosphofructo kinase (PFK), glyceraldehyde-3-phosphate dehydrogenase (GAPDH) and aldolase [94]. Of particular interest are polysin (29) and 3-O-acetyl greenwayodendrin (31). Compound $\mathbf{2 9}$ acted as a competitive reversible inhibitor against $T$. brucei PFK $\left(K_{i}\right.$ $=10 \mu \mathrm{M})$, while compound $\mathbf{3 1}$ acted as a selective inhibitor of $T$. brucei aldolase (with $\mathrm{IC}_{50} \sim 0.5 \mu \mathrm{M}$ ). Meanwhile, polyveoline (33) acted as a selective inhibitor of $T$. brucei PFK and is a mixed reversible inhibitor of T. brucei GAPDH. These compounds, therefore, represent a good 


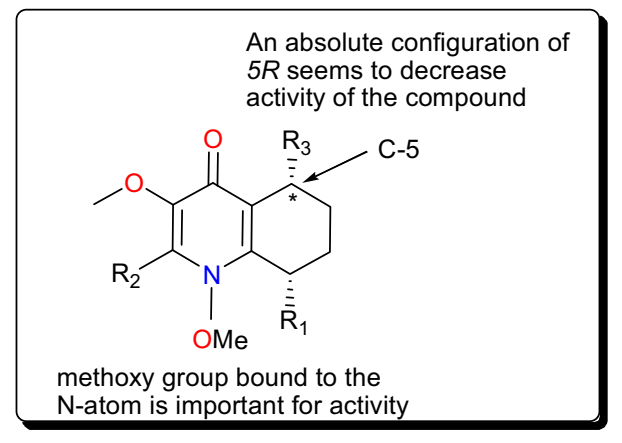

Fig. 5 SAR for $W$. indica compounds inhibiting T. cruzi, T. b. brucei and $T . b$. rhodesiense

starting point for the design of new selective and potent trypanosomal drugs.

\section{Terpenoids}

Terpenoids constitute a large and diverse class of naturally occurring secondary metabolites, with interesting physiological and pharmacological functions [44, 107-110]. Their main scaffolds occur as multicyclic structures, e.g., hemi-terpenoids (5 carbon atoms), monoterpenoids (10 carbon atoms), sesquiterpenoids ( 15 carbon atoms), diterpenoids (20 carbon atoms), sesterterpenoids (25 carbon atoms), triterpenoids (30 carbon atoms), tetraterpenoids (40 carbon atoms), and polyterpenoids (more than 40 carbon atoms), which are all primarily derived from the five-carbon isoprene units [45, 107]. Terpenoids have been proven to possess interesting pharmacological activities as seen in the summary presented in Table 2 (compounds 34-61) and their corresponding structures shown in Figs. 6, 7, 8, 9 and 10 [44, 111-114].

\subsection{Sesquiterpenoids}

The sesquiterpenoids (Fig. 6), muzigadiolide (34), muzigadial (35), 6 $\alpha, 9 \alpha$-dihydroxy-4(13),7-coloratadiene-11,12dial (36), mukaadial (37) and ugandensidial (38), from the East African medicinal plant Warburgia ugandensis (Canellaceae) have demonstrated anti-Trypanosoma activities [115]. The compounds displayed in vitro activities (with $\mathrm{IC}_{50}$ values ranging from 0.64 to $6.4 \mu \mathrm{M}$ ) against $T$. $b$. rhodesiense, the parasite responsible for African sleeping sickness. Compound $\mathbf{3 7}$ had previously been isolated from the same plant, also showing antitrypanocidal activity [116]. This plant (now regarded as an endangered species) has attracted many researchers because of its traditional use for the treatment of a variety of ailments, including malaria and diverse fevers [115-117]. SAR studies suggested that an additional dialdehyde functional group to the sesquiterpene lactone backbone, together with a hydroxyl group attached to C-9 contribute to the activity of the compounds.

\subsection{Carvotacetone Derivatives}

The native tropical East African medicinal plant Sphaeranthus bullatus (synonym: S. gallensis Sacleux, Family: Asteraceae) has been the origin of several compounds (Fig. 7) [118-120], including the carvotacetone derivatives; 3-acetoxy-7-hydroxy-5-tigloyloxycarvotacetone (39), 3,7-dihydroxy-5-tigloyloxycarvotacetone (40) and 3-acetoxy-5,7-dihydroxycarvotacetone (41). Compounds 39-41 demonstrated antileishmanial activities, with $\mathrm{IC}_{50}$ values of $2.16,10.64$ and $2.89 \mu \mathrm{M}$, respectively, against the parasite $L$. donovanii promastigotes.

\subsection{Diterpenoids}

Other terpenoids include the abietane diterpenoids, taxodione (42) and uncinatone (43), Fig. 8, from the roots of Clerodendrum eriophyllum (Verbenaceae) [121], which displayed potent antileishmanial activities (with $\mathrm{IC}_{50}$ values of 0.25 and $0.61 \mu \mathrm{M}$, respectively) against $L$. donovanii. The activities of the crude extracts, e.g., the ethyl acetate extracts of Newbouldia laevis (Bignoniaceae) $\left(\mathrm{EC}_{50}\right.$ $4.2 \mu \mathrm{g} / \mathrm{mL}$ ) and Eucalyptus maculata (Myrtaceae) $\left(\mathrm{EC}_{50}\right.$ $12.3 \mu \mathrm{g} / \mathrm{mL}$ ) and the hexane extract of Polyalthia longifolia (Annonaceae) $\left(\mathrm{EC}_{50} 2.4 \mu \mathrm{g} / \mathrm{mL}\right.$ ) as well as their isolated active compounds (Fig. 8); 16- $\alpha$-hydroxy-cleroda3-13(-14)z-dien-15,16-olide (44), kolavenic acid (45),

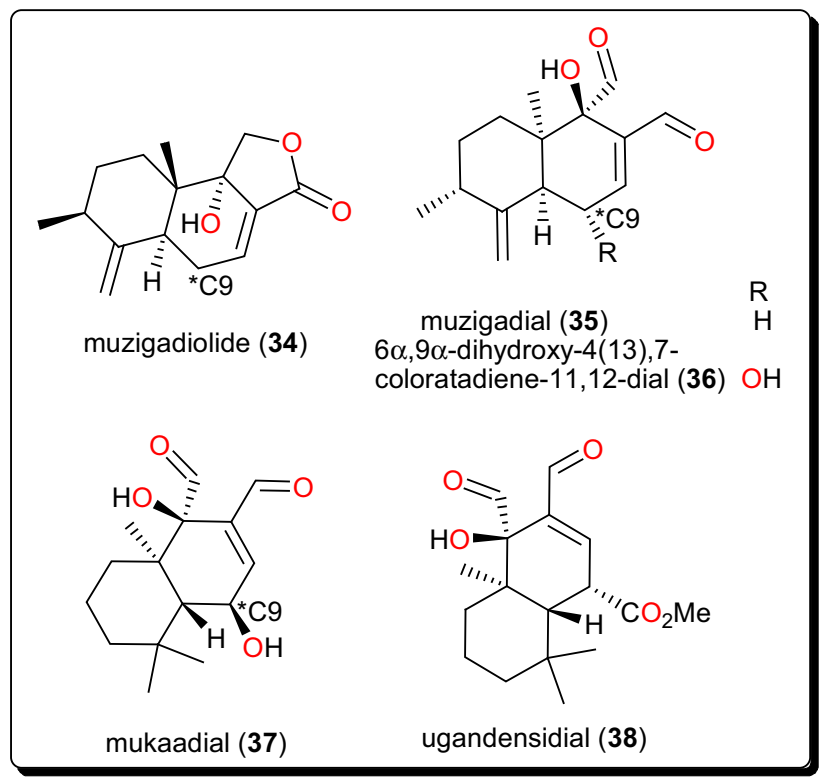

Fig. 6 Sesquiterpenoids which have demonstrated anti-Trypanosoma activities 


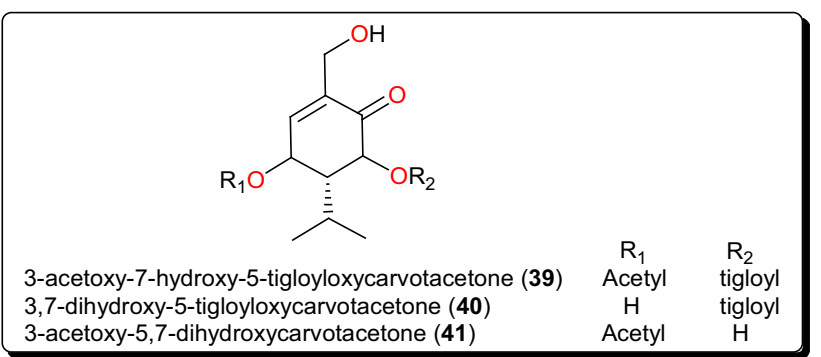

Fig. 7 Carvotacetones with potent antileishmanial activities

polyalthiadioic acid (46) and the triterpenoid $3 \beta, 13 \beta$-dihydroxy-urs-11-en-28-oic acid (47) were observed against different trypanosomes strains (s427 WT, B48 and AQP2/ 3KO) [122]. While these pure compounds exhibited activities against the tested strains, with $\mathrm{EC}_{50}$ values ranging from 1.16 to $40.46 \mu \mathrm{M}$, it was remarkable that no toxicity towards Human Embryonic Kidney cells was observed even at concentrations up to $400 \mu \mathrm{g} / \mathrm{mL}$ $(1.31 \mu \mathrm{M})$, thus suggesting new scaffolds to be further developed for the treatment of the wild-type and multi-drug resistant T. brucei $[122,123]$. Also interesting is the kolavic acid derivative; monomethyl ester-15-kolavic acid (48) isolated from Entada abyssinica (Fabaceae) [124], which demonstrated interesting selective inhibitory activity ( $\mathrm{IC}_{50}$ value of $12 \mu \mathrm{M}$ ) against $T$. brucei GAPDH [125].

Other bioactive diterpenoids include 15-oxo-ent-kaur16-en-19-oic acid (49), 15 $\alpha$-acetoxy-ent-kaur-16-en-19-oic acid or xylopic acid, (50) and 16,17-epoxy-15-oxo-entkauran-19-oic acid or xylopioxyde (51), from the fruits of Xylopia aethiopica (Annonaceae) [126]. These compounds and their synthetic epoxide analogues were screened on antitrypanosomal and cytotoxicity assays, showing that only the naturally-occurring compounds (49-51) displayed cytotoxic effects on the mammalian fibroblast cell line MRC-5 (with $\mathrm{ED}_{50}$ values ranging from 22 to $121 \mu \mathrm{M}$ ), as well as inhibitory effects on the growth of the bloodstream forms of T. b. brucei cells (strain 241) ( $\mathrm{ED}_{50}$ ranging from 27 to $205 \mu \mathrm{M})$.

The genus Aframomum (Zingiberaceae), has been the source of the antitryposonomals. Sceptrumlabdalactone B (52, Fig. 9) was identified, from the rhizomes of A. sceptrum, a plant locally used for the treatment of infectious diseases including human African Trypanosomiasis (sleeping sickness), together with sceptrumlabdalactone A [127, 134-136]. The activity of compound $\mathbf{5 2}$ (with $\mathrm{IC}_{50}$ value of $5.7 \mu \mathrm{M}$ ) against $L$. donovani was comparable to that of reference drugs $\left(\mathrm{IC}_{50}\right.$ of 2.5 and $3.0 \mu \mathrm{M}$ for pentamidine and miltefosine respectively). Additionally, this molecule demonstrated selective activity for $L$. donovani, when compared with the activity against $T$. b. brucei.

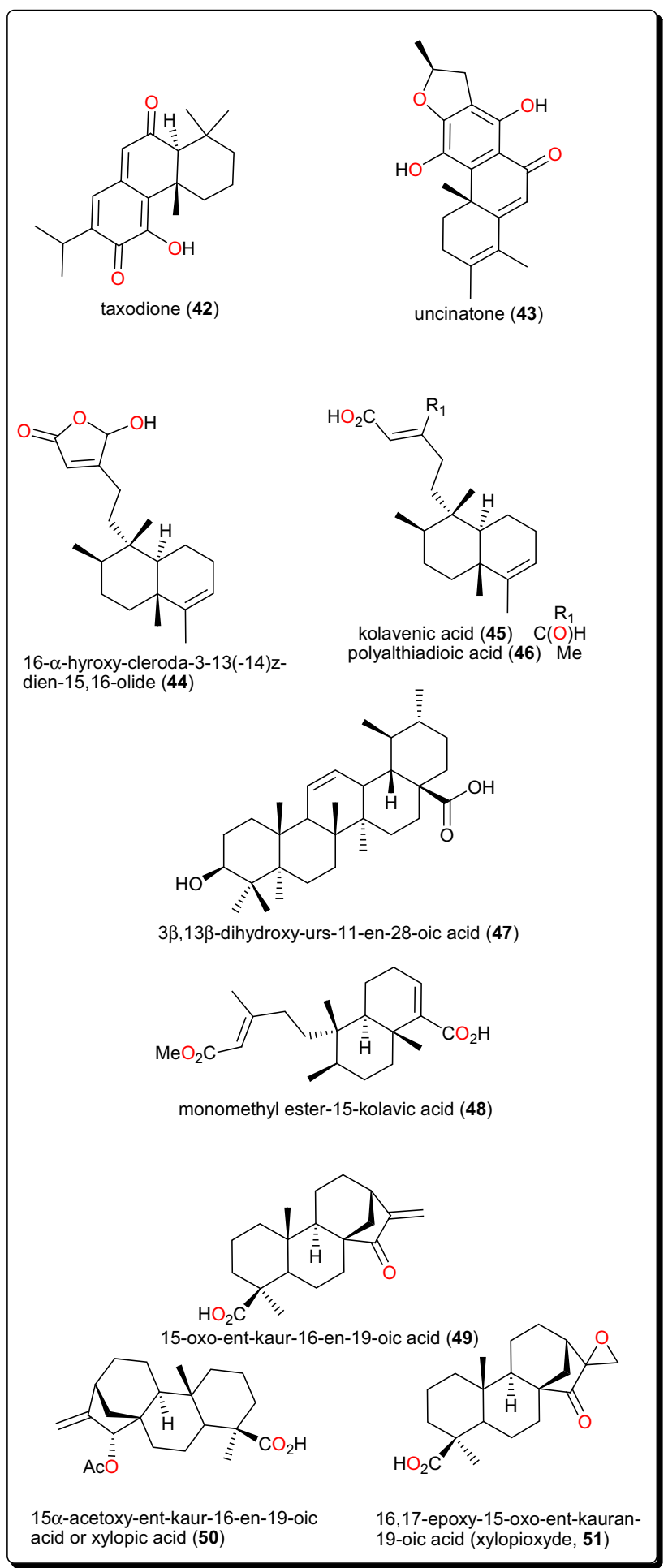

Fig. 8 Diterpenoids and a triterpenoid with selective inhibitory activity against $T$. brucei GAPDH

\subsection{Triterpenoids}

The anti-schistosomal activity of Asparagalin A (53, Fig. 10), from the Egyptian medicinal plant Asparagus 


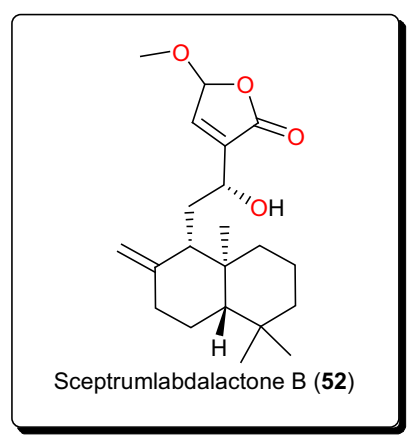

Fig. 9 Potent compound with selective activity for $L$. donovani, when compared with the activity against $T . b$. brucei

stipularis (Asparagaceae) has been evaluated [128]. It was found that this compound was able to significantly reduce the ability of adult female worms to lay eggs. It was further shown that the compound had some suppressive effect on egg-laying capacity in a dose-dependence manner [137]. Elaeodendron schlechteranum (Celastraceae) is the source of tingenin B or 22ß-hydroxytingenone (54) [129]. This compound has displayed a broad range of activities, e.g., against $T$. cruzi $\left(\mathrm{IC}_{50}<0.57 \mu \mathrm{M}\right)$, . brucei $(<0.57 \mu \mathrm{M}), L$. infantum $(1.67 \mu \mathrm{M})$, and $P$. falciparum $(0.83 \mu \mathrm{M})$, confirming the claim of the applicability of the plant in traditional medicine to treat various non-infectious diseases $[63,138]$. Albeit, being highly cytotoxic to MRC-5 cells $\left(\mathrm{CC}_{50} 0.45 \mu \mathrm{g} / \mathrm{mL}\right)$, compound $\mathbf{5 4}$ indicates a poor selectivity to normal cells. Further studies on this compound could be considered in order to suggest less toxic and more selective analogues for the development of novel antiparasitics. The bisnortriterpenes from Salacia madagascariensis (Celastraceae); isoiguesterin (55) and 20-epi-isoiguesterinol (56) showed potent activities against Leishmania sp. [130]. Meanwhile, isoiguesterin (55) and 20-epi-isoiguesterinol (56) displayed comparable activities with chloroquine and artemisinin against the D6 clone, being more potent and selective against $L$. donovani (a species known to cause visceral Leishmaniasis). When compared with amphotericin B, used currently in the treatment of Leishmaniasis, compounds $\mathbf{5 5}$ and $\mathbf{5 6}$ show great potential for future selective drug development against Leishmania.

Keetia leucantha (synonym: Plectronia leucantha Krause) is a West African tree of the Rubiaceae, used to treat a variety of infections, including parasitic infections [139, 140]. Ursolic acid (57) and oleanolic acid (58), along with other constituents were isolated from the leaves of this plant. An investigation of the antitrypanosomal activities of essential oil, the dichloromethane extract and isolated compounds on $T$. $b$. brucei bloodstream forms ( $T b b \mathrm{BSF}$ ) and procyclic forms (Tbb PF) [131] showed that ursolic acid (57) and oleanolic acid (58) were the most bioactive

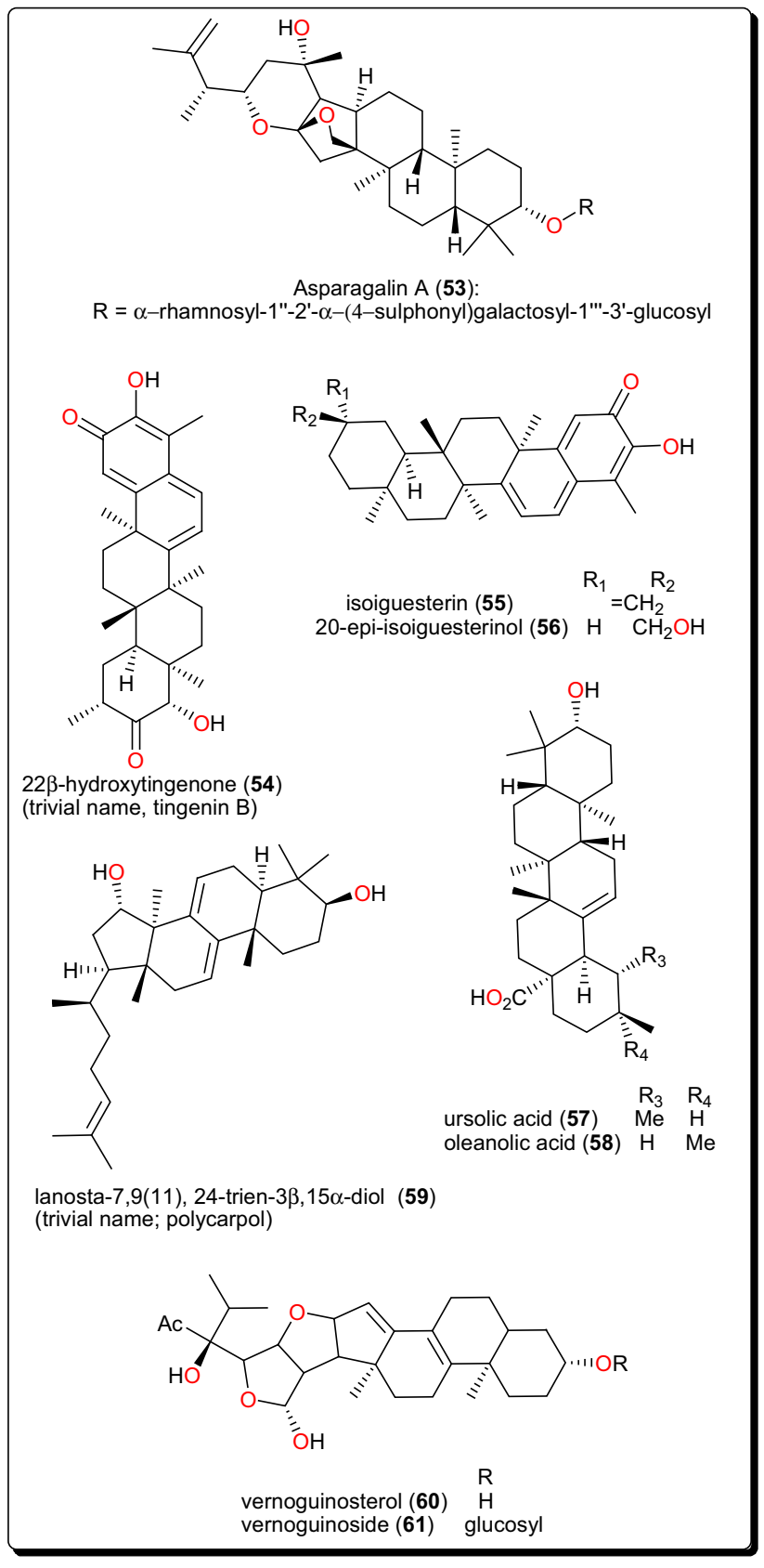

Fig. 10 Triterpenoids with antiparasitic activities

tested compounds [131]. Ursolic acid displayed $\mathrm{IC}_{50}$ values of 5.48 and $14.25 \mu \mathrm{M}$, respectively, on $T b b$ BSF and $T b b$ $\mathrm{PF}$, while oleanolic acid displayed an $\mathrm{IC}_{50}$ value of $16.00 \mu \mathrm{M}$ on $T b b$ BSF. This could explain why the plant is effective in the traditional treatment of related parasitic ailments. Another identified triterpenoid was polycarpol or lanosta-7,9(11),24-trien-3 $\beta, 15 \alpha$-diol (59) from Piptostigma preussi (Annonaceae) [132]. The compound showed antitrypanosomal activity with an $\mathrm{ED}_{50}$ value of $5.11 \mu \mathrm{M}$ on T. brucei cells. An investigation of its mode of action showed that the compound acted by inhibiting T. brucei 
glycolytic enzymes GAPDH and PFK (glycolytic pathway enzymes validated by WHO as good targets for the development of drugs against trypanosomiasis), with $\mathrm{IC}_{50}$ values of 650 and $180 \mu \mathrm{M}$, respectively. The glycolytic enzymes GAPDH are responsible for ATP production and have been reported to be vital for the survival of Trypanosomatids [141, 142]. From the stem bark of Vernonia guineensis (Asteraceae), vernoguinosterol (60) and vernoguinoside (61), exhibited interesting trypanocidal activity with $\mathrm{IC}_{50}$ values in the range 4.60-7.67 $\mu \mathrm{M}$ [133].

\section{Other Compound Classes}

Other compound classes from AMP with reported activities on Leishmaniasis and Trypanosomiasis are shown in Figs. 11, 12, 13, 14, and 15, while a summary of the reported molecules is given in Table 3 (compounds 62-82).

\subsection{Amides}

Plants from the genus Zapoteca (Fabaceae) have been the origin of diverse compounds with antiprotozoal activities. These include the ester 2-(2-benzamido-3-phenylpropanamido)-3-phenylpropyl acetate (trivial names; saropeptide or aurantiamide acetate) $(\mathbf{6 2})$ from $Z$. portoricensis (Fig. 11) [143]. The $\mathrm{IC}_{50}$ values of compound $\mathbf{6 2}$ were 3.63, 41.65 and $92.05 \mu \mathrm{M}$ against $T$. b. rhodesiense, $T$. cruzi and against rat skeletal myoblast cell line (L6 cells), respectively. The compound had been previously reported to possess anti-inflammatory as well as antiplatelet aggregation activities, which are complementary to the observed trypanocidal property [144-148]. Since inflammation poses major problems in the advanced stages of Trypanosomiasis, compound $\mathbf{6 2}$ represents a promising natural hit with a reasonable selectivity for $T$. $b$. rhodesiense.

\subsection{Diarylhepanoids}

Other potent antitrypanosomal compounds are the diarylheptanoid; letestuianin C (63) and (4Z,6E)-5-hydroxy-1,7bis(4-hydroxyphenyl)hepta-4,6-dien-3-one (64) from the species Aframomum letestuianum, Fig. 11 [136]. The activities of compounds $63(4.49 \mu \mathrm{M})$ and $64(8.39 \mu \mathrm{M})$ validate the use of the Aframomum sp. in treating parasitic ailments amongst others.

\subsection{Acylphloroglucinols and Xanthones}

Guttiferone A (65), garcinol (66), cambogin (67) and guttiferone F (68) from Allanblackia monticola (Guttiferae or Clusiaceae) fruits and xanthone $\mathrm{V}_{1}(\mathbf{6 9})$ from Symphonia globulifera leaves have shown antileishmanial activities

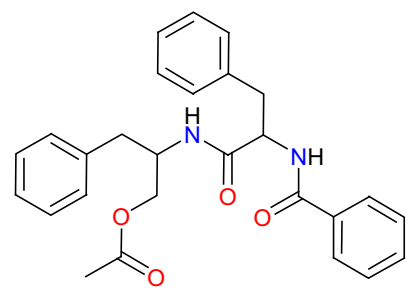

2-(2-benzamido-3-phenylpropanamido)-3-phenylpropyl acetate (62) (trivial names: saropeptideor aurantiamide acetate)

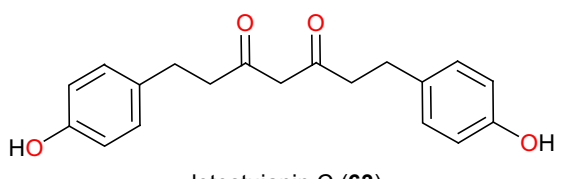

letestuianin C (63)

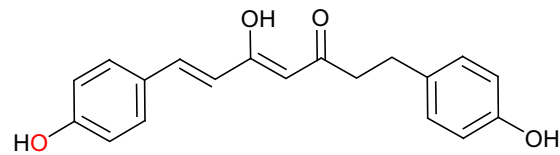

(4Z,6E)-5-hydroxy-1,7-bis(4-hydroxyphenyl)hepta-4,6-dien-3-one (64)

Fig. 11 An antitrypansomal amide and two diarylhepanoids

(Fig. 12) [149]. The compounds exhibited very potent in vitro antileishmanial activities, particularly compounds 65-67, with $\mathrm{IC}_{50}$ values of $0.16,0.33$ and $0.2 \mu \mathrm{M}$, for compounds 65, 66 and 67, respectively. These were lower than that of the reference drug, miltefosine $(0.46 \mu \mathrm{M})$. SAR studies could further improve the activities of these compounds in order to enhance their selectivity indices against human cancer cell lines.

\subsection{Taccalonolides}

Beside their proven anticancer potential, these represent a quite potent class of antitrypanosomal compounds identified from Tacca leontopetaloides (Taccaceae) [157-162]. These include taccalonolide A 12-propanoate (70), taccalonolide $\mathrm{T}(\mathbf{7 1})$ and taccalonolide $\mathrm{S}(\mathbf{7 2})$ from the tubers of T. leontopetaloide (Fig. 13). They have shown activities against the T. b. brucei s427 lister strain [150]. These compounds and crude fractions yielded $\mathrm{EC}_{50}$ values as low as $0.79 \mu \mathrm{g} / \mathrm{mL}$.

\subsection{Quiniones and Klaivanolide}

Quinones from Aloe species have also shown antileishmanial activities. These include aloinoside (73), aloin (74) and microdontin (75) from the leaf latex of A. calidophila (Fig. 14) [151]. It is noteworthy that, the activities of the most potent compounds, with $\mathrm{IC}_{50}$ values ranging from 3.12 to $10.92 \mu \mathrm{M}$ against Leishmania aethiopica and from 


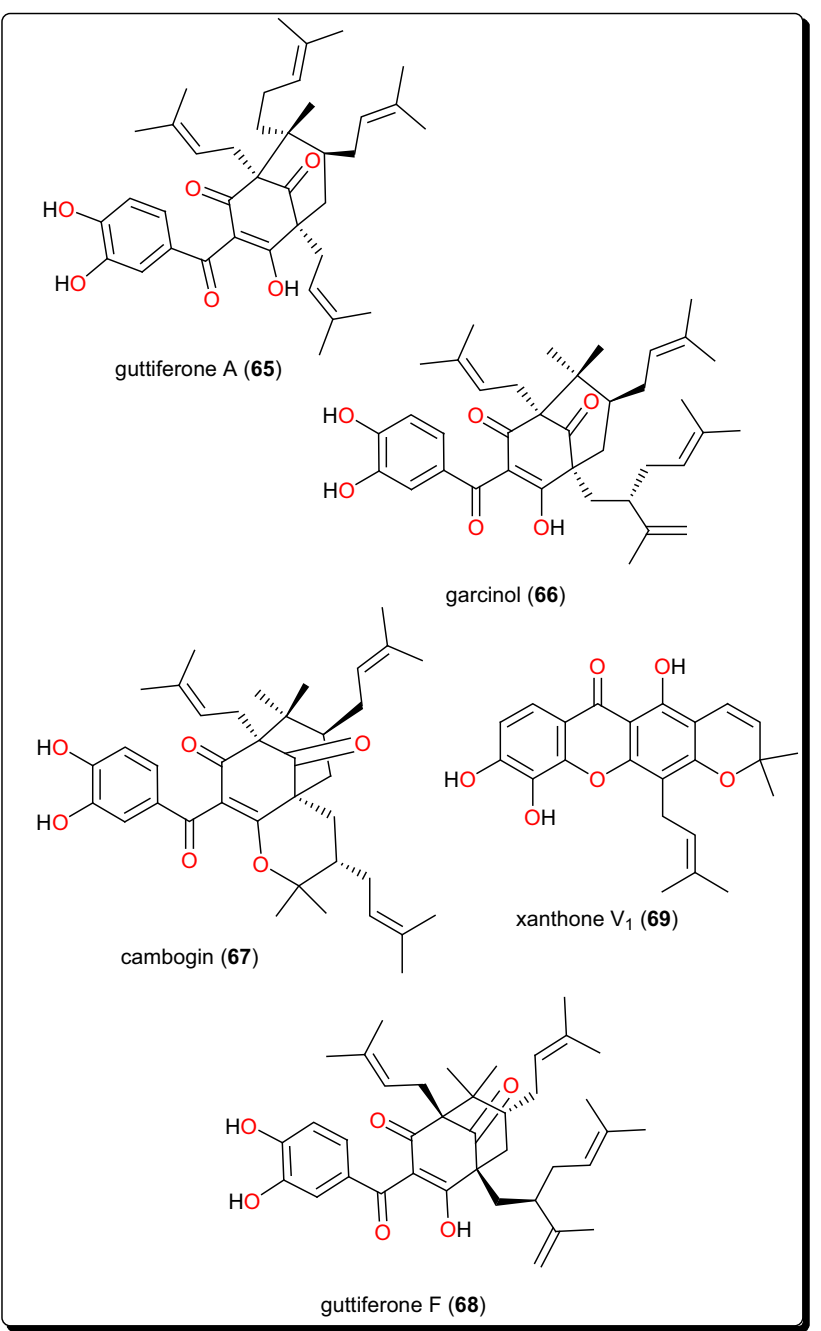

Fig. 12 Acylphloroglucinols and a xanthone with very potent in vitro antileishmanial activities in the nanomolar range

3.70 to $15.26 \mu \mathrm{M}$ against Leishmania major, were comparable to the control drug amphotericin $\mathrm{B}\left(\mathrm{IC}_{50}=0.12\right.$ and $0.07 \mu \mathrm{M}$ against $L$. aethiopica and L. major respectively). The selectivity indices of aloinoside (73) (813.35 and 694.90, respectively, against $L$. aethiopica and $L$. major) were much better than those of the control, amphotericin B (423.49 and 688.96, respectively). This suggests that the isolated compounds could serve as potential scaffolds for the development of safe, specific and cost-effective antileishmanial agents [151]. Additionally, the dioncoquinones A (76) and B (77) isolated from Triphyophyllum peltatum (Dioncophyllaceae) showed good and specific activity against $L$. major by inhibiting the growth of the parasite at very low concentrations [152]. Klaivanolide (78), from the stems of Uvaria klaineana (Annonaceae), was also reported as a potent molecule (in vitro $\mathrm{IC}_{50}$ values of 1.75 and $3.12 \mu \mathrm{M}$, respectively)

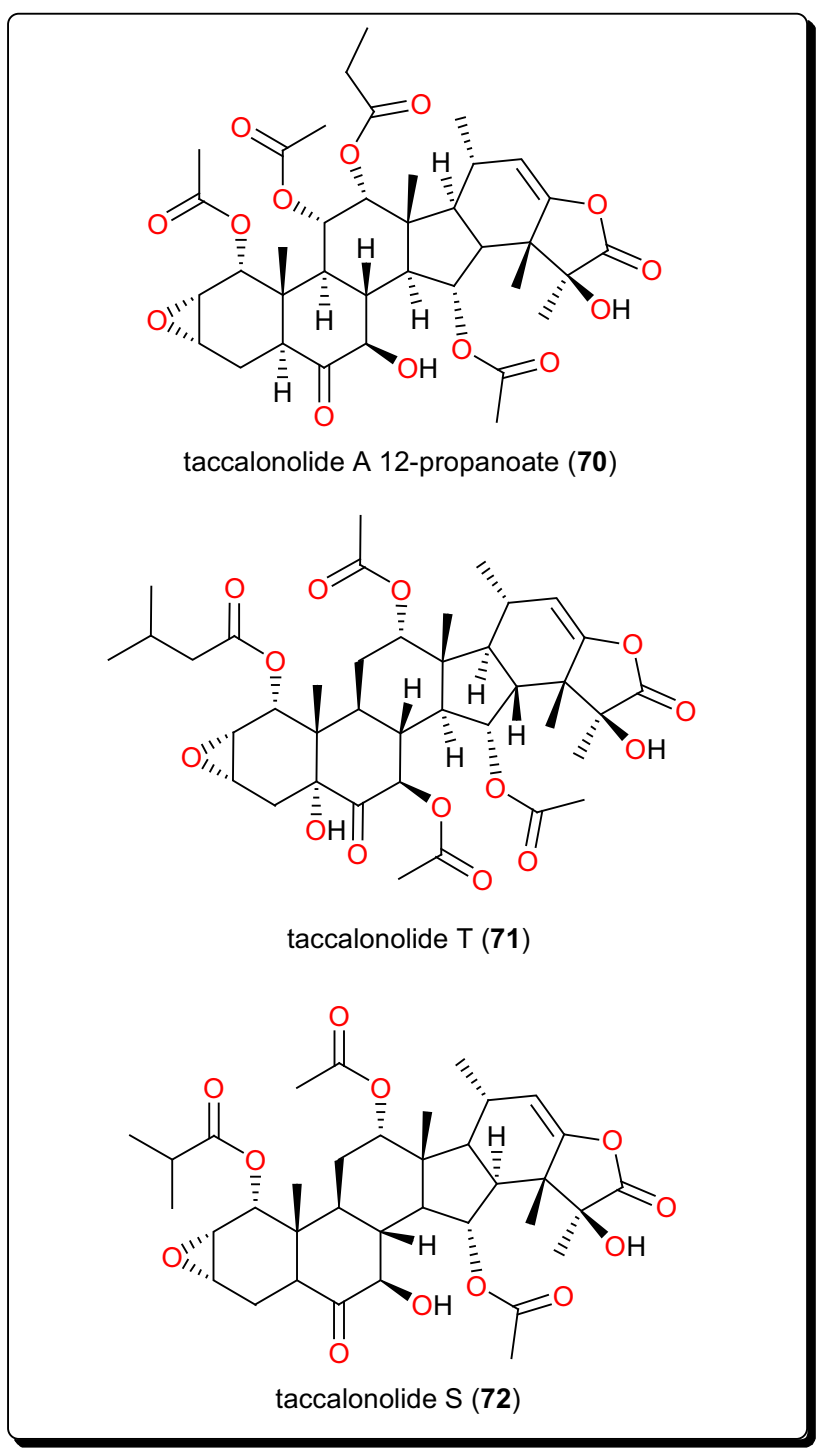

Fig. 13 Taccalonolides, a rare class of antiprotozoals

against sensitive and amphotericin B-resistant promastigote forms of L. donovani [153].

\subsection{Flavonoids}

Artemetin (79, Fig. 15), from Vitex simplicifolia (Verbenaceae) leaves, exhibited promising trypanocidal activity with an $\mathrm{IC}_{50}$ value of $4.7 \mu \mathrm{g} / \mathrm{mL}$ and a selectivity index of 9.8 against L6 cells [154]. While this activity confirms the use of this plant in the traditional treatment of ailments including parasitic diseases [163-165], phytochemical evaluation of trypanocidal activities were not reported before. Hence, the plant could further be investigated for the unidentified compounds. An investigation of Ageratum conyzoides (Asteraceae), a plant known for its importance 


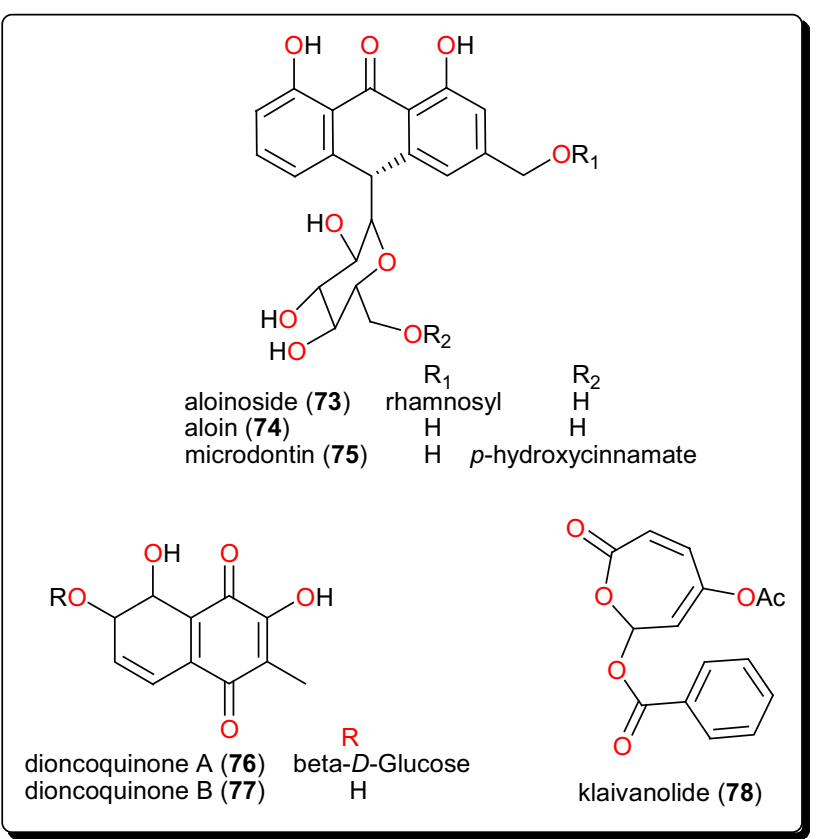

Fig. 14 Quiniones and klaivanolide, which showed lower micromolar activities against against several Leishmania species

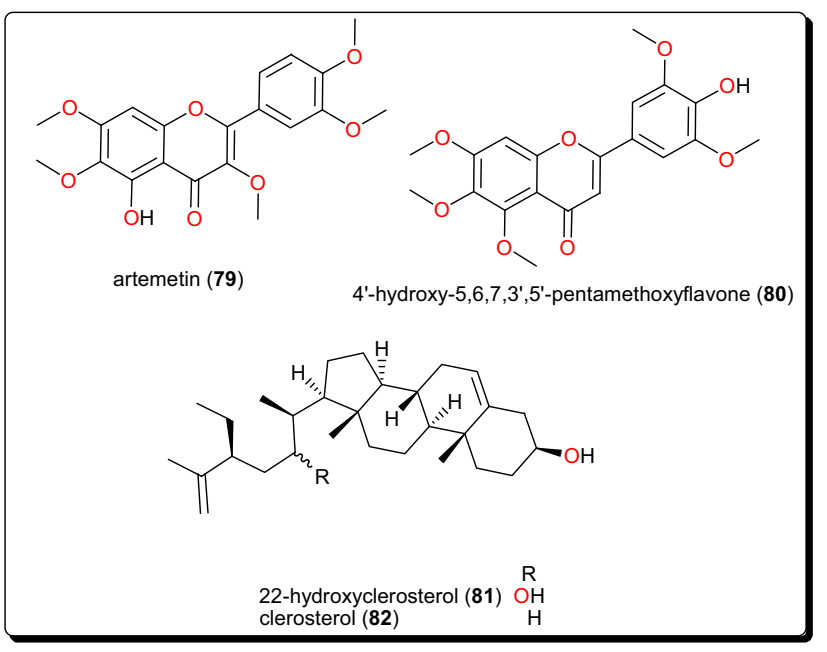

Fig. 15 Flavonoids and phytosterols with trypanocidal activities

in the treatment of sleeping sickness patients traditionally $[155,166,167]$, led to the isolation of several flavonoids; $5,6,7,8,5^{\prime}$-pentamethoxy- $3^{\prime}, 4^{\prime}$-methylenedioxyflavone (trivial name: eupalestin), 5,6,7,5'-tetramethoxy-3', $4^{\prime}$-methylene-

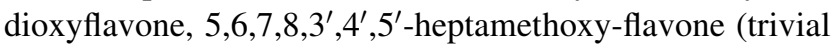

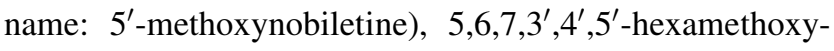
flavone and $4^{\prime}$-hydroxy-5,6,7,3', $5^{\prime}$-pentamethoxyflavone (trivial name: ageconyflavone $\mathrm{C}, \mathbf{8 0}$ ) which displayed antiprotozoal activities, some in the lower micromolar range [155]. Among the tested NPs, compound $\mathbf{8 0}$ showed the highest activity against $T$. b. rhodesiense and $L$. donovani with $\mathrm{IC}_{50}$ values of 7.8 and $9.2 \mu \mathrm{M}$ respectively.
However, all the isolated compounds showed an activity weaker than that of the crude extract, implying that the activities of the compounds in the mixture could be synergistic.

\subsection{Phytosterols}

22-Hydroxyclerosterol (81) and clerosterol (82), Fig. 15, were isolated from the stem bark of Allexis cauliflora (Violaceae) [155]. These compounds were evaluated for trypanocidal activities, and the activity of compound $\mathbf{8 1}$ $\left(\mathrm{ED}_{50}=1.12 \mu \mathrm{M}\right)$ was far better than that of compound $\mathbf{8 2}$ $\left(\mathrm{ED}_{50}=134.34 \mu \mathrm{M}\right)$. These results prompted an investigation of their cytotoxic activities. It was observed that compound $\mathbf{8 1}$ inhibited mammalian cells at quite a similar concentration $\left(\mathrm{ED}_{50}=1.56 \mu \mathrm{M}\right)$, while compound 82 had no effect. This difference in activity could be attributed to the presence of the hydroxyl group at C-22 in the side chain of compound $\mathbf{8 1}$ which is absent in compound 82. Additionally, it was observed that compound $\mathbf{8 1}$ was more active and selective on the parasite enzyme glycolytic enzymes (PGI and GAPDH), when compared with compound $\mathbf{8 2}$.

\section{Conclusions}

Parasitic diseases continue to represent a menace on a global scale and require attention due to lack of vaccines and reported resistance against available drugs for their treatment. This review focuses on different natural compounds and scaffolds that could lead drug discovery research groups into reasonable starting points for further development of fast, effective and affordable novel molecules for the treatment of parasitic diseases. Drug discovery and development now place efforts on the search for new moieties or chemical scaffolds of natural/semisynthetic origin and in the development of phytomedicines. As a means to facilitate accessibility of information, our research team has as one of its goals, to develop free online natural products libraries from African flora (http://africancompounds.org/). In this paper, an attempt has been made to draw together original research works on natural products from AMP with micromolar range activities against Schistosoma, Trypanosoma and Leishmania species. The compounds presented herein have demonstrated a diverse range of activities against different forms of Trypanosomiasis, Schistosomiasis and Leishmaniasis, with some scaffolds and molecules showing great potential as starting points for further development into drugs. We recently collected a dataset of several hundred bioactive plant based metabolites from AMPs with activities against Trypanosoma sp. (Afrotryp) [68]. It becomes interesting to 
perform in silico prediction of binding modes and binding free energy calculations of some of the compounds against some selected targets.

Acknowledgements CVS is currently a Ph.D. student funded by the German Academic Exchange Services (DAAD). FNK currently holds a Georg Forster postdoctoral fellowship from the Alexander von Humboldt Foundation, Germany.

\section{Compliance with Ethical Standards}

Conflict of interest The authors declare no conflict of interest.

Open Access This article is distributed under the terms of the Creative Commons Attribution 4.0 International License (http://creative commons.org/licenses/by/4.0/), which permits unrestricted use, distribution, and reproduction in any medium, provided you give appropriate credit to the original author(s) and the source, provide a link to the Creative Commons license, and indicate if changes were made.

\section{References}

1. P. Mansueto, A. Seidita, G. Vitale, A. Cascio, Travel Med. Infect. Dis. 12, 563-581 (2014)

2. B.Y. Lee, K.M. Bacon, M.E. Bottazzi, P.J. Hotez, Lancet Infect. Dis. 13, 342-348 (2013)

3. T.N. Wells, P.L. Alonso, W.E. Gutteridge, Nat. Rev. Drug Discov. 8, 879-891 (2009)

4. F. Ntie-Kang, P.A. Onguene, L.L. Lifongo, J.C. Ndom, W. Sippl, L.M. Mbaze, Malar. J. 13, 81 (2014)

5. M.C. Nunes, W. Dones, C.A. Morillo, J.J. Encina, A.L. Ribeiro, Council on Chagas Disease of the Interamerican Society of Cardiology, J. Am. Coll. Cardiol. 62, 767-776 (2013)

6. P.G. Kennedy, Lancet Neurol. 12, 186-194 (2013)

7. H. de Vries, A.P. Wagelmans, E. Hasker, C. Lumbala, P. Lutumba, S.J. de Vlas, J.V. Klundert, PLoS Comput. Biol. 12, e1005103 (2016)

8. N.K. Copeland, N.E. Aronson, Curr. Opin. Infect. Dis. 28, 426-437 (2015)

9. D.G. Colley, A.L. Bustinduy, W.E. Secor, C.H. King, Lancet 383, 2253-2264 (2014)

10. D. Rollinson, S. Knopp, S. Levitz, J.R. Stothard, L.A. Tchuem Tchuente, A. Garba, K.A. Mohammed, N. Schur, B. Person, D.G. Colley, J. Utzinger, Acta Trop. 128, 423-440 (2013)

11. M. Noma, H.G. Zoure, A.H. Tekle, P.A. Enyong, B.E. Nwoke, J.H. Remme, Parasit. Vector 7, 325 (2014)

12. H.G. Zoure, M. Noma, A.H. Tekle, U.V. Amazigo, P.J. Diggle, E. Giorgi, J.H. Remme, Parasit Vectors 7, 326 (2014)

13. World Health Organization. Accessed 10 January 2018 (2017)

14. D.J. Gray, A.G. Ross, Y.S. Li, D.P. McManus, Br. Med. J. 342, d2651 (2011)

15. A. Olotu, G. Fegan, J. Wambua, G. Nyangweso, A. Leach, M. Lievens, D.C. Kaslow, P. Njuguna, K. Marsh, P. Bejon, N Engl. J. Med. 374, 2519-2529 (2016)

16. E.H. Ntege, N. Arisue, D. Ito, T. Hasegawa, N.M.Q. Palacpac, T.G. Egwang, T. Horii, E. Takashima, T. Tsuboi, Vaccine 34, 5612-5622 (2016)

17. K.E. Lyke, A.S. Ishizuka, A.A. Berry, S. Chakravarty, A. DeZure, M.E. Enama, E.R. James, P.F. Billingsley, A. Gunasekera, A. Manoj, M. Li, A.J. Ruben, T. Li, A.G. Eappen, R.E. Stafford, K.C. Natasha, T. Murshedkar, F.H. Mendoza, I.J.
Gordon, K.L. Zephir, L.A. Holman, S.H. Plummer, C.S. Hendel, L. Novik, P.J.M. Costner, J.G. Saunders, N.M. Berkowitz, B.J. Flynn, M.C. Nason, L.S. Garver, M.B. Laurens, C.V. Plowe, T.L. Richie, B.S. Graham, M. Roederer, B.K.L. Sim, J.E. Ledgerwood, S.L. Hoffman, R.A. Seder, Proc. Natl. Acad. Sci. USA 114, 2711-2716 (2017)

18. B. Hanboonkunupakarn, N.J. White, Trop. Dis. Travel Med. Vaccines 2, 10 (2016)

19. B. Blasco, D. Leroy, D.A. Fidock, Nat. Med. 23, 917-928 (2017)

20. J.P. Webster, D.H. Molyneux, P.J. Hotez, A. Fenwick, Philos. Trans. R. Soc. Lond. B 369, 20130434 (2014)

21. M.J. Doenhoff, J.R. Kusel, G.C. Coles, D. Cioli, Trans. R. Soc. Trop. Med. Hyg. 96, 465-469 (2002)

22. T. Heimburg, A. Chakrabarti, J. Lancelot, M. Marek, J. Melesina, A.T. Hauser, T.B. Shaik, S. Duclaud, D. Robaa, F. Erdmann, M. Schmidt, C. Romier, R.J. Pierce, M. Jung, W. Sippl, J. Med. Chem. 59, 2423-2435 (2016)

23. M. Ismail, S. Botros, A. Metwally, S. William, A. Farghally, L.F. Tao, T.A. Day, J.L. Bennett, Am. J. Trop. Med. Hyg. 60, 932-935 (1999)

24. M.J. Doenhoff, D. Cioli, J. Utzinger, Curr. Opin. Infect. Dis. 21, 659-667 (2008)

25. S.G. Sparg, J. van Staden, A.K. Jager, J. Ethnopharmacol. 73, 209-214 (2000)

26. D.A. Stolfa, M. Marek, J. Lancelot, A.T. Hauser, A. Walter, E. Leproult, J. Melesina, T. Rumpf, J.M. Wurtz, J. Cavarelli, W. Sippi, R.J. Pierce, C. Romier, M. Jung, J. Mol. Biol. 426, 3442-3453 (2014)

27. K.T. Andrews, A. Haque, M.K. Jones, Immunol. Cell Biol. 90, 66-77 (2012)

28. P.J. Hotez, A. Kamath, PLoS Negl. Trop. D 3, e412 (2009)

29. R. Brun, J. Blum, F. Chappuis, C. Burri, Lancet 375, 148-159 (2010)

30. World Health Organization (WHO). Chagas disease (American trypanosomiasis). http://www.who.int/mediacentre/factsheets/ fs340/en/. Accessed 9 November 2017 (2017)

31. World Health Organization (WHO). Trypanosomiasis, human African (sleeping sickness). http://www.who.int/mediacentre/ factsheets/fs259/en/. Accessed 9 November 2017 (2017)

32. P.P. Simarro, J. Jannin, P. Cattand, PLoS Med. 5, 174-180 (2008)

33. S. Aksoy, P. Buscher, M. Lehane, P. Solano, J. Van Den Abbeele, PLoS Negl. Trop. Dis. 11, e0005454 (2017)

34. J.R. Franco, P.P. Simarro, A. Diarra, J.A. Ruiz-Postigo, J.G. Jannin, Parasitology 141, 748-760 (2014)

35. P.D. Ready, Clin. Epidemiol. 6, 147-154 (2014)

36. S. Aluru, M. Hide, G. Michel, A.L. Banuls, P. Marty, C. Pomares, Parasite 22, 16 (2015)

37. World Health Organization (WHO). Leishmaniasis. http://www. who.int/mediacentre/factsheets/fs 375/en/. Accessed 9 November 2017 (2017)

38. F.R. Martins-Melo, M.D. Lima, A.N. Ramos, C.H. Alencar, J. Heukelbach, PLoS ONE 9, e93770 (2014)

39. A.I. Einzig, H. Hochster, P.H. Wiernik, D.L. Trump, J.P Dutcher, E. Garowski, J. Sasloff, T.J. Smith, Invest. New Drugs 9, 59-64 (1991)

40. M.C. Wani, H.L. Taylor, M.E. Wall, P. Coggon, A.T. McPhail, J. Am. Chem. Soc. 93, 2325-2327 (1971)

41. G.M. Rishton, Am. J. Cardiol. 101, 43d-49d (2008)

42. J.D. Phillipson, Phytochemistry 56, 237-243 (2001)

43. G.A. Cordell, Phytochem. Lett. 10, 28-40 (2014)

44. F. Ntie-Kang, L.L. Lifongo, C.V. Simoben, S.B. Babiaka, W. Sippl, L.M. Mbaze, RSC Adv. 4, 35348-35370 (2014)

45. F. Ntie-Kang, L.L. Lifongo, C.V. Simoben, S.B. Babiaka, W. Sippl, L.M. Mbaze, RSC Adv. 4, 28728-28755 (2014) 
46. C.V. Simoben, F. Ntie-Kang, L.L. Lifongo, S.B. Babiaka, W. Sippl, L.M. Mbaze, RSC Adv. 4, 40095-40110 (2014)

47. I. Tietjen, F. Ntie-Kang, P. Mwimanzi, P.A. Onguene, M.A. Scull, T.O. Idowu, A.O. Ogundaini, L.M. Meva'a, B.M. Abegaz, C.M. Rice, K. Andrae-Marobela, M.A. Brockman, Z.L. Brumme, D. Fedida, PLoS ONE 10, e0121099 (2015)

48. D.J. Newman, G.M. Cragg, K.M. Snader, Nat. Prod. Rep. 17, 215-234 (2000)

49. B.E. van Wyk, J. Ethnopharmacol. 119, 342-355 (2008)

50. A.L. Harvey, R. Edrada-Ebel, R.J. Quinn, Nat. Rev. Drug Discov. 14, 111-129 (2015)

51. M.A. Ibrahim, A. Mohammed, M.B. Isah, A.B. Aliyu, J. Ethnopharmacol. 154, 26-54 (2014)

52. F. Ntie-Kang, L.L. Lifongo, L.M. Mbaze, N. Ekwelle, L.C. Owono Owono, E. Megnassan, P.N. Judson, W. Sippl, S.M. Efange, BMC Complement. Altern. Med. 13, 147 (2013)

53. L.L. Lifongo, C.V. Simoben, F. Ntie-Kang, S.B. Babiaka, P.N. Judson, Nat. Prod. Bioprospect 4, 1-19 (2014)

54. F. Ntie-Kang, D. Zofou, S.B. Babiaka, R. Meudom, M. Scharfe, L.L. Lifongo, J.A. Mbah, L.M. Mbaze, W. Sippl, S.M. Efange, PLoS ONE 8, e78085 (2013)

55. H.M. Adamu, O.J. Abayeh, M.O. Agho, A.L. Abdullahi, A. Uba, H.U. Dukku, B.M. Wufem, J. Ethnopharmacol. 99, 1-4 (2005)

56. F.B. Magassouba, A. Diallo, M. Kouyate, F. Mara, O. Mara, O. Bangoura, A. Camara, S. Traore, A.K. Diallo, M. Zaoro, K. Lamah, S. Diallo, G. Camara, S. Traore, A. Kaita, M.K. Camara, R. Barry, S. Keita, K. Oulare, M.S. Barry, M. Donzo, K. Camara, K. Tote, D. Vanden Berghe, J. Totte, L. Pieters, A.J. Vlietinck, A.M. Balde, J. Ethnopharmacol. 114, 44-53 (2007)

57. T. Brendler, B.E. van Wyk, J. Ethnopharmacol. 119, 420-433 (2008)

58. I.P. Dike, O.O. Obembe, F.E. Adebiyi, J. Ethnopharmacol. 144, 618-626 (2012)

59. L. Kambizi, A.J. Afolayan, J. Ethnopharmacol. 77, 5-9 (2001)

60. K.A. Abo, A.A. Fred-Jaiyesimi, A.E.A. Jaiyesimi, J. Ethnopharmacol. 115, 67-71 (2008)

61. J.S. Ashidi, P.J. Houghton, P.J. Hylands, T. Efferth, J. Ethnopharmacol. 128, 501-512 (2010)

62. S. Semenya, M. Potgieter, L. Erasmus, J. Ethnopharmacol. 141, 440-445 (2012)

63. S.M. Maregesi, O.D. Ngassapa, L. Pieters, A.J. Vlietinck, J. Ethnopharmacol. 113, 457-470 (2007)

64. World Health Organization. Accessed 7 January 2017. (2004)

65. C. Vonthron-Senecheau, B. Weniger, M. Ouattara, F.T. Bi, A. Kamenan, A. Lobstein, R. Brun, R. Anton, J. Ethnopharmacol. 87, 221-225 (2003)

66. O. Jansen, L. Angenot, M. Tits, J.P. Nicolas, P. De Mol, P.Y. Sacre, M.C. Jonville, M. Frederich, Planta Med. 74, 1142 (2008)

67. A.W. Mbaya, U.I. Ibrahim, Int. J. Pharmacol. 7, 1-11 (2011)

68. A. Ibezim, B. Debnath, F. Ntie-Kang, C.J. Mbah, N.J. Nwodo, Med. Chem. Res. 26, 562-579 (2017)

69. N.J. Nwodo, A. Ibezim, F. Ntie-Kang, M.U. Adikwu, C.J. Mbah, Molecules 20, 7750-7771 (2015)

70. S. Hoet, F. Opperdoes, R. Brun, J. Quetin-Leclereq, Nat. Prod. Rep. 21, 353-364 (2004)

71. I.V. Ogungbe, W.N. Setzer, Molecules 14, 1513-1536 (2009)

72. T.J. Schmidt, S.A. Khalid, A.J. Romanha, T.M. Alves, M.W. Biavatti, R. Brun, F.B. Da Costa, S.L. de Castro, V.F. Ferreira, M.V.G. de Lacerda, J.H.G. Lago, L.L. Leon, N.P. Lopes, R.C.D. Amorim, M. Niehues, I.V. Ogungbe, A.M. Pohlit, M.T. Scotti, W.N. Setzer, M.D.C. Soeiro, M. Steindel, A.G. Tempone, Curr. Med. Chem. 19, 2128-2175 (2012)

73. T.J. Schmidt, S.A. Khalid, A.J. Romanha, T.M.A. Alves, M.W. Biavatti, R. Brun, F.B. Da Costa, S.L. de Castro, V.F. Ferreira, M.V.G. de Lacerda, J.H.G. Lago, L.L. Leon, N.P. Lopes, R.C.D. Amorim, M. Niehues, I.V. Ogungbe, A.M. Pohlit, M.T. Scotti,
W.N. Setzer, M.D.C. Soeiro, M. Steindel, A.G. Tempone, Curr. Med. Chem. 19, 2176-2228 (2012)

74. F. Ntie-Kang, K.K. Telukunta, K. Doring, C.V. Sirnoben, A.F.A. Moumbock, Y.I. Malange, L.E. Njurne, J.N. Yong, W. Sippl, S. Gunther, J. Nat. Prod. 80, 2067-2076 (2017)

75. F. Ntie-Kang, Springerplus 2, 353 (2013)

76. A. Inada, R. Ogasawara, I. Koga, N. Nakatani, Y. Inatomi, H. Murata, M. Nishi, T. Nakanishi, Chem. Pharm. Bull. 56, 727-729 (2008)

77. K.P. Devkota, J.D. Wansi, B.N. Lenta, S. Khan, M.I. Choudhary, N. Sewald, Planta Med. 76, 1022-1025 (2010)

78. L. Cheesman, J.J. Nair, J. van Staden, J. Ethnopharmacol. 140, 405-408 (2012)

79. B.B. Mishra, R.R. Kale, R.K. Singh, V.K. Tiwari, Fitoterapia 80, 81-90 (2009)

80. B.V. Tsassi, H. Hussain, A. Geagni, E. Dongo, I. Ahmed, M. Riaz, K. Krohn, Helv. Chim. Acta 94, 1035-1040 (2011)

81. A. Ndagijimana, X.M. Wang, G.X. Pan, F. Zhang, H. Feng, O. Olaleye, Fitoterapia 86, 35-47 (2013)

82. C.O. Nnadi, N.J. Nwodo, M. Kaiser, R. Brun, T.J. Schmidt, Molecules 22, 1129 (2017)

83. P.F. Uzor, W. Ebrahim, P.O. Osadebe, J.N. Nwodo, F.B. Okoye, W.E.G. Muller, W.H. Lin, Z. Liu, P. Proksch, Fitoterapia 105, 147-150 (2015)

84. T.C. Okoye, P.A. Akah, A.C. Ezike, P.F. Uzor, U.E. Odoh, S.O. Igboeme, U.B. Onwuka, S.N. Okafor, BMC Complement. Altern. Med. 14, 376 (2014)

85. G. Bringmann, M. Dreyer, J.H. Faber, P.W. Dalsgaard, D. Staerk, J.W. Jaroszewski, H. Ndangalasi, F. Mbago, R. Brun, S.B. Christensen, J. Nat. Prod. 67, 743-748 (2004)

86. G. Bringmann, M. Dreyer, J.H. Faber, P.W. Dalsgaard, D. Staerk, J.W. Jaroszewski, H. Ndangalasi, F. Mbago, R. Brun, M. Reichert, K. Maksimenka, S.B. Christensen, J. Nat. Prod. 66, 1159-1165 (2003)

87. G. Bringmann, A. Hamm, C. Gunther, M. Michel, R. Brun, V. Mudogo, J. Nat. Prod. 63, 1465-1470 (2000)

88. G. Bringmann, K. Messer, R. Brun, V. Mudogo, J. Nat. Prod. 65, 1096-1101 (2002)

89. G. Bringmann, I. Kajahn, M. Reichert, S.E.H. Pedersen, J.H. Faber, T. Gulder, R. Brun, S.B. Christensen, A. Ponte-Sucre, H. Moll, G. Heubl, V. Mudogo, J. Org. Chem. 71, 9348-9356 (2006)

90. G. Bringmann, W. Saeb, M. Ruckert, J. Mies, M. Michel, V. Mudogo, R. Brun, Phytochemistry 62, 631-636 (2003)

91. G. Bringmann, K. Messer, K. Wolf, J. Muhlbacher, M. Grune, R. Brun, A.M. Louis, Phytochemistry 60, 389-397 (2002)

92. S. Hoet, C. Stevigny, S. Block, F. Opperdoes, P. Colson, B. Baldeyrou, A. Lansiaux, C. Bailly, J. Quetin-Leclercq, Planta Med. 70, 407-413 (2004)

93. S. Cretton, L. Breant, L. Pourrez, C. Ambuehl, L. Marcourt, S.N. Ebrahimi, M. Hamburger, R. Perozzo, S. Karimou, M. Kaiser, M. Cuendet, P. Christen, J. Nat. Prod. 77, 2304-2311 (2014)

94. I. Ngantchou, B. Nyasse, C. Denier, C. Blonski, V. Hannaert, B. Schneider, Bioorg. Med. Chem. Lett. 20, 3495-3498 (2010)

95. G. Bringmann, M. Dreyer, M. Michel, F.S.K. Tayman, R. Brun, Phytochemistry 65, 2903-2907 (2004)

96. M.N. Ngemenya, J.N. Hanna, J.A. Komtchou, S.M.N. Efange, Asian Pac. J. Trop. Biomed. 5, 472-477 (2015)

97. J.N. Hanna, F. Ntie-Kang, M. Kaiser, R. Brun, S.M.N. Efange, RSC Adv. 4, 22856-22865 (2014)

98. H. Montenegro, M. Gutierrez, L.I. Romero, E. Ortega-Barria, T.L. Capson, L.C. Rios, Planta Med. 69, 677-679 (2003)

99. S.E. Atawodi, D.A. Ameh, S. Ibrahim, J.N. Andrew, H.C. Nzelibe, E.O. Onyike, K.M. Anigo, E.A. Abu, D.B. James, G.C. Njoku, A.B. Sallau, J. Ethnopharmacol. 79, 279-282 (2002) 
100. M.S. Abubakar, A.M. Musa, A. Ahmed, I.M. Hussaini, J. Ethnopharmacol. 111, 625-629 (2007)

101. J.D. Olowokudejo, A.B. Kadiri, V.A. Travih, Ethnobot. Leafl. 12, 851-865 (2008)

102. M.O. Soladoye, M.O. Adetayo, E.C. Chukwuma, A.N. Adetunji, Ann. Biol. Res. 1, 1-15 (2010)

103. H. de Wet, M.N. Nkwanyana, S.F. van Vuuren, J. Ethnopharmacol. 130, 284-289 (2010)

104. H.A. Garro, M. Juri Ayub, M. Nieto, C. Lucero Estrada, C.R. Pungitore, C.E. Tonn, Cell Mol. Biol. 56(24), 1318-1323 (2010)

105. A.H. Tekle, H.G. Zoure, M. Noma, M. Boussinesq, L.E. Coffeng, W.A. Stolk, J.H. Remme, Am. J. Trop. Med. Hyg. 95, 1 (2017)

106. A. Buske, A.S. Kekule, A. Haring, G. Adam, patent WO2003000272 A1. https://www.google.com/patents/ WO2003000272A2003000271?cl=en (2003)

107. L.M. Leandro, F.D. Vargas, P.C.S. Barbosa, J.K.O. Neves, J.A. da Silva, V.F. da Veiga, Molecules 17, 3866-3889 (2012)

108. R.J. Thoppil, A. Bishayee, World J. Hepatol. 3, 228-249 (2011)

109. H. Achenbach, A. Schwinn, Phytochemistry 38, 1037-1048 (1995)

110. M.H.H. Nkunya, Pure Appl. Chem. 77, 1943-1955 (2005)

111. K. Nakano, C. Yoshida, W. Furukawa, Y. Takaishi, K. Shishido, Phytochemistry 49, 1821-1824 (1998)

112. P.A. Onguene, F. Ntie-Kang, L.L. Lifongo, J.C. Ndom, W. Sippl, L.M. Mbaze, Malar. J. 12, 449 (2013)

113. L. Faiella, A. Temraz, T. Siciliano, N. De Tommasi, A. Braca, Phytochem. Lett. 5, 297-300 (2012)

114. J.N. Nwodo, A. Ibezim, C.V. Simoben, F. Ntie-Kang, AntiCancer Agent Med. Chem. 16, 108-127 (2016)

115. A.A. Wube, F. Bucar, S. Gibbons, K. Asres, L. Rattray, S.L. Croft, Phytother. Res. 24, 1468-1472 (2010)

116. D. Olila, J. Opuda-Asibo, O. Olwa, Afr. Health Sci. 1, 12-15 (2001)

117. J.O. Kokwaro, in Medicinal plants of East Africa, 3rd edn., ed. by J.O. Kokwaro (University of Nairobi Press, Kampala, 2009), p. 215

118. F. Machumi, A. Yenesew, J.O. Midiwo, M. Heydenreich, E. Kleinpeter, B.L. Tekwani, S.I. Khan, L.A. Walker, I. Muhammad, Nat. Prod. Commun. 7, 1123-1126 (2012)

119. C.Y. Ragasa, P.W. Tsai, C.T. Galvez, C.C. Shen, Planta Med. 76, 146-151 (2010)

120. J. Jakupovic, M. Grenz, F. Bohlmann, G.M. Mungai, Phytochemistry 29, 1213-1217 (1990)

121. F. Machumi, V. Samoylenko, A. Yenesew, S. Derese, J.O. Midiwo, F.T. Wiggers, M.R. Jacob, B.L. Tekwani, S.I. Khan, L.A. Walker, I. Muhammad, Nat. Prod. Commun. 5, 853-858 (2010)

122. G.U. Ebiloma, J.O. Igoli, E. Katsoulis, A.M. Donachie, A. Eze, A.I. Gray, H.P. de Koning, J. Ethnopharmacol. 202, 256-264 (2017)

123. A.B. Aliyu, A.M. Musa, M.S. Abdullahi, A.O. Oyewale, U.S. Gwarzo, Niger. J. Pharm. Res. 7, 1-8 (2008)

124. B. Nyasse, I. Ngantchou, E.M. Tchana, B. Sonke, C. Denier, C. Fontaine, Pharmazie 59, 873-875 (2004)

125. F. Freiburghaus, E.N. Ogwal, M.H.H. Nkunya, R. Kaminsky, R. Brun, Trop. Med. Int. Health 1, 765-771 (1996)

126. D. Soh, E. Nkwengoua, I. Ngantchou, B. Nyasse, C. Denier, V. Hannaert, K.H. Shaker, B. Schneider, J Appl Pharm Sci 3, 13-19 (2013)

127. Z. Cheikh-Ali, T. Okpekon, F. Roblot, C. Bories, M. Cardao, J.C. Jullian, E. Poupon, P. Champy, Phytochem. Lett. 4, 240-244 (2011)

128. H.R. El-Seedi, R. El-Shabasy, H. Sakr, M. Zayed, A.M.A. ElSaid, K.M.H. Helmy, A.H.M. Gaara, Z. Turki, M. Azeem, A.M.
Ahmed, L. Boulos, A.K. Borg-Karlson, U. Goransson, Rev. Bras. Farmacogn. 22, 314-318 (2012)

129. S.M. Maregesi, N. Hermans, L. Dhooghe, K. Cimanga, D. Ferreira, C. Pannecouque, D.A. Vanden Berghe, P. Cos, L. Maes, A.J. Vlietinck, S. Apers, L. Pieters, J. Ethnopharmacol. 129, 319-326 (2010)

130. D.A. Thiem, A.T. Sneden, S.I. Khan, B.L. Tekwani, J. Nat. Prod. 68, 251-254 (2005)

131. J. Bero, C. Beaufay, V. Hannaert, M.F. Herent, P.A. Michels, J. Quetin-Leclercq, Phytomedicine 20, 270-274 (2013)

132. I. Ngantchou, E. Nkwengoua, Y. Nganso, B. Nyasse, C. Denier, V. Hannaert, B. Schneider, Fitoterapia 80, 188-191 (2009)

133. A.T. Tchinda, A. Tsopmo, P. Tane, J.F. Ayafor, J.D. Connolly, O. Sterner, Phytochemistry 59, 371-374 (2002)

134. P. Tane, S.D. Tatsimo, G.A. Ayimele, J.D. Connolly, Bioactive metabolites from Aframomum species. In: 11th NAPRECA Symposium Book of Proceedings, Antananarivo, Madagascar, pp. 214-223 (2005)

135. T. Okpekon, S. Yolou, C. Gleye, F. Roblot, P. Loiseau, C. Bories, P. Grellier, F. Frappier, A. Laurens, R. Hocquemiller, J. Ethnopharmacol. 90, 91-97 (2004)

136. P. Kamnaing, A. Tsopmo, E.A. Tanifum, M.H. Tchuendem, P. Tane, J.F. Ayafor, O. Sterner, D. Rattendi, M.M. Iwu, B. Schuster, C. Bacchi, J. Nat. Prod. 66, 364-367 (2003)

137. L. Boulos, Medicinal plants of North Africa (Reference Publications, Inc., Algonac, 1983), p. 130

138. S.M. Maregesi, L. Pieters, O.D. Ngassapa, S. Apers, R. Vingerhoets, P. Cos, D.A.V. Vanden Berghe, A.J. Vlietinck, J. Ethnopharmacol. 119, 58-66 (2008)

139. J. Bero, H. Ganfon, M.C. Jonville, M. Frederich, F. Gbaguidi, P. Demol, M. Moudachirou, J. Quetin-Leclercq, J. Ethnopharmacol. 122, 439-444 (2009)

140. J. Bero, V. Hannaert, G. Chataigne, M.F. Herent, J. QuetinLeclercq, J. Ethnopharmacol. 137, 998-1002 (2011)

141. V. Hannaert, F.R. Opperdoes, P.A.M. Michels, Protein Express Purif. 6, 244-250 (1995)

142. B. Nyasse, J.J. Nono, Y. Nganso, I. Ngantchou, B. Schneider, Fitoterapia 80, 32-34 (2009)

143. N.J. Nwodo, F.B.C. Okoye, D.W. Lai, A. Debbab, R. Brun, P. Proksch, Molecules 19, 5470-5477 (2014)

144. P.C. Kuo, T.L. Hwang, Y.T. Lin, Y.C. Kuo, Y.L. Leu, Arch. Pharm. Res. 34, 715-722 (2011)

145. C.A.N. Catalan, C.S. de Heluani, C. Kotowicz, T.E. Gedris, W. Herz, Phytochemistry 64, 625-629 (2003)

146. M. Nwagwu, A.L. Inyang, R.I. Molokwu, E.M. Essien, Afr. J. Med. Med. Sci. 18, 283-287 (1989)

147. G.B.S. Lundkvist, M.T. Sellix, M. Nygard, E. Davis, M. Straume, K. Kristensson, G.D. Block, J. Biol. Rhythm. 25, 92-102 (2010)

148. V. Kuete, T. Efferth, J. Ethnopharmacol. 137, 752-766 (2011)

149. B.N. Lenta, C. Vonthron-Senecheau, B. Weniger, K.P. Devkota, J. Ngoupayo, M. Kaiser, Q. Naz, M.I. Choudhary, E. Tsamo, N. Sewald, Molecules 12, 1548-1557 (2007)

150. V.T. Dike, B. Vihiior, J.A. Bosha, T.M. Yin, G.U. Ebiloma, H.P. de Koning, J.O. Igoli, A.I. Gray, Phytochem. Anal. 27, 217-221 (2016)

151. F. Abeje, D. Bisrat, A. Hailu, K. Asres, Phytother. Res. 28, 1801-1805 (2014)

152. G. Bringmann, S. Rudenauer, A. Irmer, T. Bruhn, R. Brun, T. Heimberger, T. Stuhmer, R. Bargou, M. Chatterjee, Phytochemistry 69, 2501-2509 (2008)

153. B. Akendengue, F. Roblot, P.M. Loiseau, C. Bories, E. NgouMilama, A. Laurens, R. Hocquemiller, Phytochemistry 59, 885-888 (2002)

154. N. Nwodo, F. Okoye, D. Lai, A. Debbab, M. Kaiser, R. Brun, P. Proksch, BMC Complement. Altern. Med. 15, 82-86 (2015) 
155. A.M.M. Nour, S.A. Khalid, M. Kaiser, R. Brun, W.E. Abdalla, T.J. Schmidt, J. Ethnopharmacol. 129, 127-130 (2010)

156. Y.O. Nganso, I.E. Ngantchou, E. Nkwenoua, B. Nyasse, C. Denier, V. Hannert, B. Schneider, Sci. Pharm. 79, 137-144 (2011)

157. J.H. Jiang, H.M. Yang, Y.L. Wang, Y.G. Chen, Trop. J. Pharm. Res. 13, 635-648 (2014)

158. G. Ni, H.Z. Yang, N.J. Fu, L.L. Zhang, M.C. Wang, J. Chen, C.L. Zhang, Y. Li, X.G. Chen, R.Y. Chen, D.Q. Yu, Planta Med. 81, 247-256 (2015)

159. A. Yokosuka, Y. Mimaki, H. Sakagami, Y. Sashida, J. Nat. Prod. 65, 283-289 (2002)
160. Z.L. Chen, B.D. Wang, M.Q. Chen, Acta Chim. Sin. 46, 1201-1206 (1988)

161. J. Peng, A.L. Risinger, G.A. Fest, E.M. Jackson, G. Helms, L.A. Polin, S.L. Mooberry, J. Med. Chem. 54, 6117-6124 (2011)

162. T.I. Borokini, A.E. Ayodele, Int. J. Mod. Bot. 2, 97-102 (2012)

163. F. Liang, Z. XiangZhen, C. Lan, Med. Plants 3, 16-22 (2012)

164. A.A. Munir, J. Adel Bot. Gard. 10, 31-97 (1987)

165. R.W.J. Keay, Trees of Nigeria (Clarendon Press, Wotton-UnderEdge, 1989), pp. 340-345

166. A. Kamboj, A.K. Saluja, Int. J. Green Pharm. 2, 59-68 (2008)

167. A.L. Okunade, Fitoterapia 73, 1-16 (2002) 